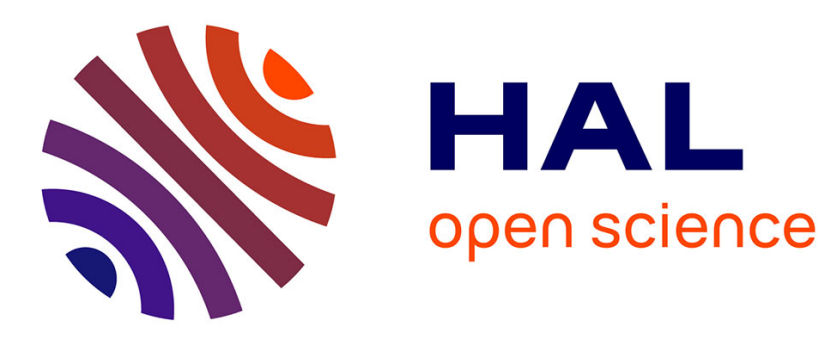

\title{
Towards Visible-Light Photocatalytic Reduction of Hypercoordinated Silicon Species
}

Etienne Levernier, Christophe Levêque, Etienne Derat, Louis Fensterbank, Cyril Ollivier

\section{- To cite this version:}

Etienne Levernier, Christophe Levêque, Etienne Derat, Louis Fensterbank, Cyril Ollivier. Towards Visible-Light Photocatalytic Reduction of Hypercoordinated Silicon Species. Helvetica Chimica Acta, 2019, 103 (1), pp.e1900238. 10.1002/hlca.201900238 . hal-03428919

\section{HAL Id: hal-03428919 https://hal.science/hal-03428919}

Submitted on 15 Nov 2021

HAL is a multi-disciplinary open access archive for the deposit and dissemination of scientific research documents, whether they are published or not. The documents may come from teaching and research institutions in France or abroad, or from public or private research centers.
L'archive ouverte pluridisciplinaire HAL, est destinée au dépôt et à la diffusion de documents scientifiques de niveau recherche, publiés ou non, émanant des établissements d'enseignement et de recherche français ou étrangers, des laboratoires publics ou privés. 


\title{
Towards Visible-Light Photocatalytic Reduction of Hypercoordinated Silicon Species
}

\author{
Etienne Levernier ${ }^{\mathrm{a}}$, Christophe Lévêque ${ }^{\mathrm{a}}$, Etienne Derat ${ }^{\mathrm{a}}$, Louis Fensterbank ${ }^{\mathrm{a} *}$ and Cyril Ollivier $^{\mathrm{a} *}$ \\ a Sorbonne Université, CNRS, Institut Parisien de Chimie Moléculaire, 4 Place Jussieu, CC 229, F-75252 Paris Cedex 05, France. \\ louis.fensterbank@sorbonne-universite.fr, cyril.ollivier@sorbonne-universite.fr \\ Dedicated to Philippe Renaud in celebration of his $60^{\text {th }}$ birthday and with all our friendship
}

\begin{abstract}
Nowadays, the quest of new radical precursors based on heteroatom complexes occupies an increasingly important position in contemporary research. Herein, we investigated the behavior and the limitations of hexa- or pentacoordinated organochlorosilanes and related pentacoordinated silyliums as new families of complexes for the generation of radicals under photocatalytic reductive conditions. Particularly, treatment of chlorophenylbis[N,Spyridine-2-thiolato(-)]silicon(IV) or the related silylium derivative with the $f a c-\operatorname{Ir}(\mathrm{ppy})_{3}\left(5 \mathrm{~mol}^{2}\right) / \mathrm{NEt}_{3}$ (1.5 equiv) system under blue LEDs irradiation generates a thiopyridyl radical which can participate in the formation of a carbon-sulfur bond by reaction with an allylsulfone. Computational studies supported this experimental finding, and particulary by showing that homolytic fragmentation of C-Ts bond is favored over the fragmentation of thiopyridyl radical.
\end{abstract}

Keywords: chlorosilane, silylium, hypercoordinated silicon compounds, photoreduction, radical, cyclic voltammetry, carbon-sulfur bond, allylation

\section{Introduction}

Over the last few decades, organosilicon compounds have received a great deal of attention in organic synthesis, ${ }^{1}$ and particularly radical synthetic chemistry, with the generation of transient silicon-centered radicals from silyl hydrides, ${ }^{2,3}$ behaving both as an effective mediator of radical reactions starting from a range of radical precursors (halides, chalcogens, xanthates, etc...) and as substrates for radical functionalization such as the hydrosilylation of unsaturated systems. ${ }^{2,3}$ The homolytic $\mathrm{Si}-\mathrm{H}$ cleavage can be obtained for instance with the (TMS) $)_{3} \mathrm{SiH}$ Chatgilialoglu's reagent ${ }^{2,4}$ or the $\mathrm{Et}_{3} \mathrm{SiH} / \mathrm{RSH}$ system for polarity reversal catalysis introduced by Roberts. ${ }^{5}$ More anecdotal, silyl radicals can be generated by photolysis of a $\mathrm{Si}-\mathrm{B}$ bond for the silylboration of olefins ${ }^{6}$ or by photocatalytic oxidation of the supersilanol (TMS) ${ }_{3} \mathrm{SiOH}$ to perform halogen abstraction for Nickel/photoredox $\mathrm{sp}^{3}$-sp ${ }^{3}$ cross-coupling reactions. ${ }^{7}$ As another interesting property, organosilicons with an activated C-Si bond as well as hypercoordinated - penta- or hexacoordinated - silicon derivatives ${ }^{8}$ have revealed as a potential source of carbon-centered radicals under oxidative conditions, which can participate in further synthetic transformations.

A SET oxidation-desilylation of benzyltrimethysilanes involving visiblelight excited chiral iminium ions ${ }^{9 \mathrm{a}}$ or 9-mesityl-10-methylacridinium perchlorate salt ${ }^{\mathrm{b} b}$ as a catalytic and strong photooxidant, allowed the formation of benzylic radicals which can be trapped by ground-state iminium ions or Michael-type acceptors respectively. In the same vein, $\alpha$ alkoxymethyl radicals were successfully generated from the corresponding $\alpha$-silyl ethers ${ }^{10}$ by photocatalyzed oxidation, as well as acyl radicals from acyl silanes. ${ }^{11}$ But interestingly, what about the reactivity of hypercoordinated silicon derivatives under oxidative conditions? This question was first answered by Kumada who reported the oxidation of organopentafluorosilicates to provide organic radicals which can react with a second equivalent of copper chloride and liberate the chlorinated product. However, this transformation required stoichiometric amount of copper salts and the low solubility of these substrates limits their use for synthesis. ${ }^{12}$ In that context, Nishigaishi reported the photoallylation ${ }^{13}$ of benzyl-type derivatives and dicyanobenzene with the more soluble allyl bis-catecholato silicate ${ }^{14}$ but these studies were limited to the generation of allylic radical. Following our initial work on the oxidation of alkyltrifluoroborates in $2010,{ }^{15}$ we prepared a series of bench stable alkyl biscatecholato silicates with a low oxidation potential (< $1 \mathrm{~V}$ vs. SCE) and tested them under visible-light photooxidative condition ${ }^{16 a}$ in order to generate functionalized alkyl radicals and particularly primary ones. ${ }^{16,17}$ The scope of substrates for simple radical trapping and also for photoredox/nickel dual catalysis proved to be quite large from primary to tertiary radicals. ${ }^{16,18}$

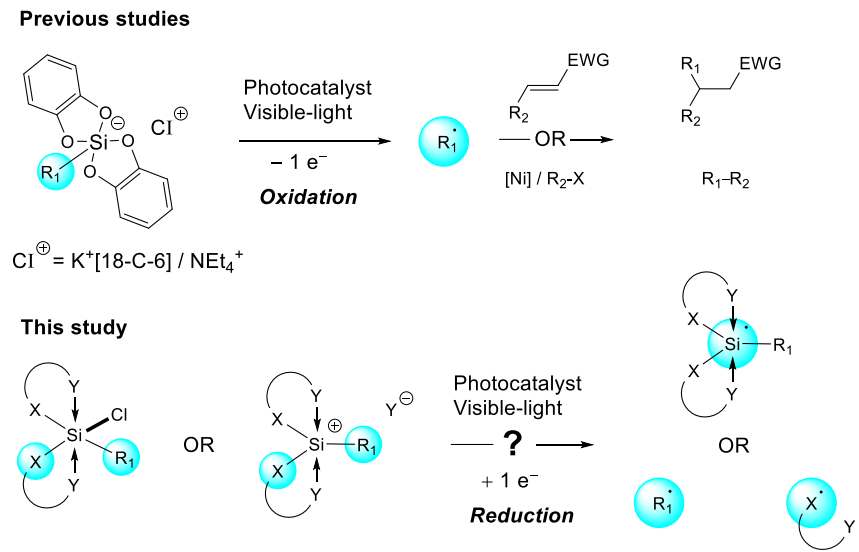

Scheme 1. Hypercoordinated silicon compounds as a source of radicals under photooxidative or photoreductive conditions 
To date, the use of hypercoordinated silicon derivatives in radical synthesis has been limited to the generation of radicals under oxidative regimes and no attempt has been already made in a reductive manner. Herein, we reported the first results regarding the behavior of hypercoordinated chlorosilanes and the related cationic silicon derivatives under visible-light photoreductive conditions to generate radical species. We presumed that the presence of hypercoordinated ligands or the formation of silylium salts would favor the labilization of the $\mathrm{Si}-\mathrm{Cl}$ bond during the reduction step to provide the formation of hypercoordinated silyl radicals. The latter may subsequently expel a carbon- or heteroatomcentered radical ( $R_{1}$ or $X$, respectively) (Scheme 1 ).

\section{Results and Discussion}

We thus tested the photoreduction of a set of hypercoordinated chlorosilanes whose synthesis has been already described in the literature. We started to investigate the reactivity of hexacoordinated silicons with bidentate $\mathrm{N}, \mathrm{O}$ ligands such as 8-oxyquinolinato ligands. We first prepared compound 1a from phenytrichlorosilane and 8-hydroxyquinoline using the procedure developed by Wägler in 2014 (Scheme 2) ${ }^{19}$ We tried to evaluate the reduction potential of 1 a by cyclic voltammetry (CV) but, due to the insolubility of this organosilicon in acetonitrile and THF, it could not be determined. Nevertheless, we explored the photoreduction of $1 \mathrm{a}$ using the highly reductant photocatalyst fac-Ir(ppy) $3\left(5 \mathrm{~mol} \%, \mathrm{E} \operatorname{Ir}(\mathrm{IV}) / \operatorname{Ir}(\mathrm{III})^{*}=\right.$ $-1.7 \mathrm{~V}$ vs SCE) under blue LEDs irradiation in the presence 1.5 equiv. of allyl sulfone 2 as a radical acceptor and 1.5 equiv. of $\mathrm{N}, \mathrm{N}$ diisopropylethylamine (DIPEA) as sacrificial electron donor for the regeneration of the photocatalyst (Scheme 2). Whatever the nature of the solvent (o.1 mol/L), acetonitrile $\left(\mathrm{CH}_{3} \mathrm{CN}\right)$ or dimethylformamide (DMF), no reaction occurred leaving the allylsulfone 1a unchanged. $n$-Butyl and benzyl chlorosilanes were also efficiently synthetized (respectively $86 \%$ and $84 \%$ yield) and investigated but no appreciable improvement of the solubility was evident.
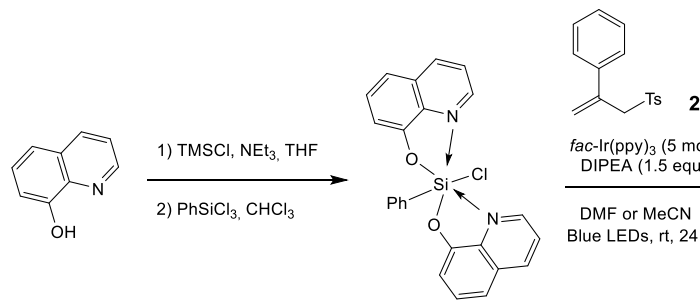

\section{fac-Ir(ppy $)_{3}(5 \mathrm{~mol} \%)$} DIPEA (1.5 equiv) No reaction DMF or MeCN Blue LEDs, rt, $24 \mathrm{~h}$

1a $71 \%$

Scheme 2. Synthesis of hexavalent silicon compound 1a with 8-oxyquinolinato ligands and reactivity in the presence of allylsulfone 2 under visible-light photoreductive conditions

In a second phase, we looked at more soluble silicon derivatives. In 2012, Tacke's group reported the formation of pentacoordinate chlorosilicon(IV) complexes with tridentate dianionic $\mathrm{O}, \mathrm{N}, \mathrm{O}$ ligands such as the tridentate 2-((E)-((Z)-4-hydroxypent-3-en-2-ylidene)amino)phenol ligand. ${ }^{20}$ We then synthesized the corresponding complex 3 as reported in scheme 3 and measured its reduction potential by $\mathrm{CV}$. To our delight, we were pleased to see that the reduction potential of the hypercoordinated species 3 is higher than the tetravalent phenyl trichlorosilane $\left(\mathrm{PhSiCl}_{3}\right)$, i.e. $-1.31 \mathrm{~V}$ vs SCE compared to $-1.51 \mathrm{~V}$ vs SCE (see cyclic voltammogram of 3 and SI, scheme 4). This suggests that this tridentate ligand significantly increases the ability of the chlorosilane to be reduced. Compound 3 was then subjected to the same reaction conditions used for $\mathbf{1 a}$, but again no reaction was evidenced by TLC and confirmed by ${ }^{1} \mathrm{H}$ NMR (Scheme 3 ). Only starting materials were recovered. Even after addition of additives such as TMSI or TMSOTf in order to generate in situ the corresponding electron deficient silylium derivatives $4 \mathrm{a}$ and $4 \mathrm{~b}$ (not characterized) ${ }_{1}^{21}$ no product was obtained and only degradation was observed. Switching from fac-Ir(ppy $)_{3}$ to a highly reducting organic photocatalyst such as $\mathrm{N}$ phenylphenothiazine (Ph-PTZ) (E Ph-PTZ ${ }^{+}$/ P Ph-PTZ* $=-2.5$ V vs SCE), ${ }^{22}$ did not afford any product either.

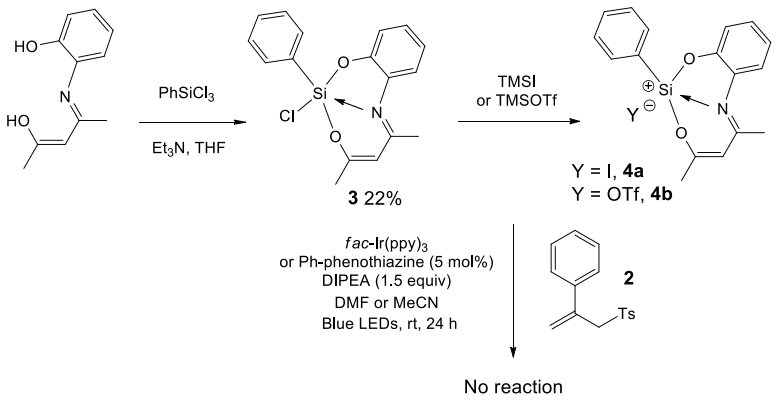

Scheme 3. Synthesis of pentavalent silicon compound 3, using 2-((E)-((Z)-4hydroxypent-3-en-2-ylidene)amino)phenol ligand, and the corresponding silylium derivatives $\mathbf{4} \mathbf{a}$ and $\mathbf{4} \mathbf{b}$ as well as their reactivity in the presence of allylsulfone $\mathbf{2}$ under visible-light photoreductive conditions

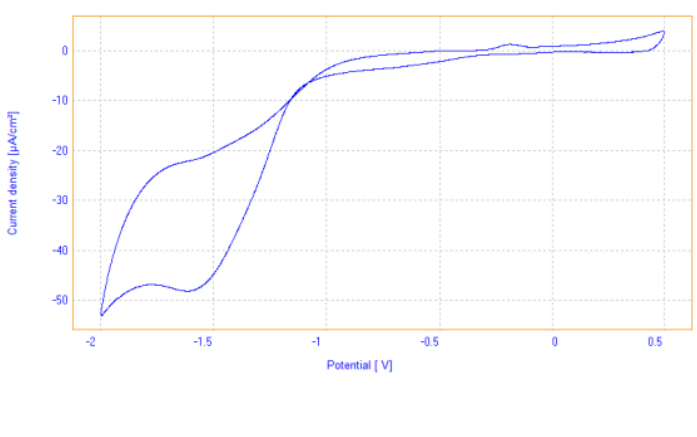

Scheme 4. Electrochemical studies: Cyclic voltammogram of 3 (10 mM) performed at $22^{\circ} \mathrm{C}$ in dried and degassed THF containing $\mathrm{Bu}_{4} \mathrm{NPF}_{6}(100 \mathrm{mM})$ as the supporting

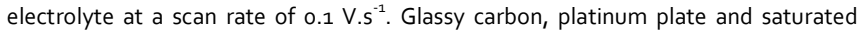
calomel were used respectively as working, counter and reference electrodes respectively.

Thereafter, we were particularly interested in the photoreduction of hexacoordinated silicon complexes with two bidentate ligands N,S- 
pyridine-2-thiolato. ${ }^{21}$ In this case, we may benefit from the possible stabilization of the generated silyl radical by the sulfur atom as already observed in the disulfure bond. ${ }^{23}$ Chlorophenylbis[N,S-pyridine-2thiolato(-)]silicon(IV) (5a) was then synthesized following the protocol reported by Tacke in 2013 as outlined in scheme $\mathbf{5}$. Its reduction potential can be estimated by CV and showed a value of about $-1.28 \mathrm{~V}$ vs SCE

(Scheme 6), higher than the reduction potentials previously determined for the hypercoordinated silicon species 3 (vide supra). This increase of potential should facilitate the reduction of compound $5 \mathbf{a}$ by the excited state of the photocatalyst fac-Ir(ppy) ${ }_{3}$ (Scheme 5 ). This substrate was then treated under the same conditions as $\mathbf{1 a}$ and $\mathbf{3}$. Allylsulfide 6, resulting from the addition of the ligand 2-thiopyridine to the allylsulfone $\mathbf{2}$, was obtained in a $24 \%$ yield. We wondered if the yield in 6 can be improved and if this transformation involves a radical or an ionic pathway.
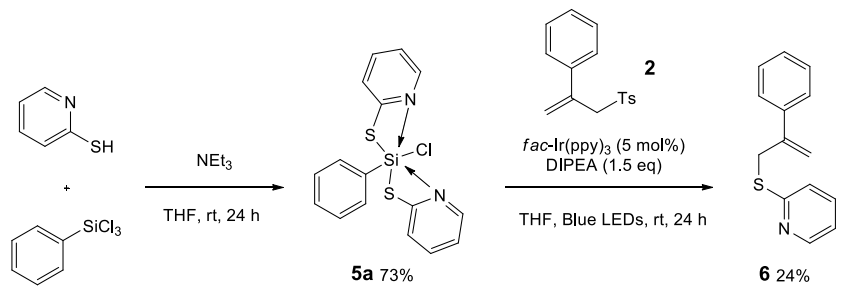

Scheme 5. Synthesis of pentavalent silicon compound 5 a, using N,S-pyridine-2thiolato ligand followed by their reactivity in the presence of allylsulfone $\mathbf{2}$ under visible-light photoreductive conditions. Formation of allylsulfide 6

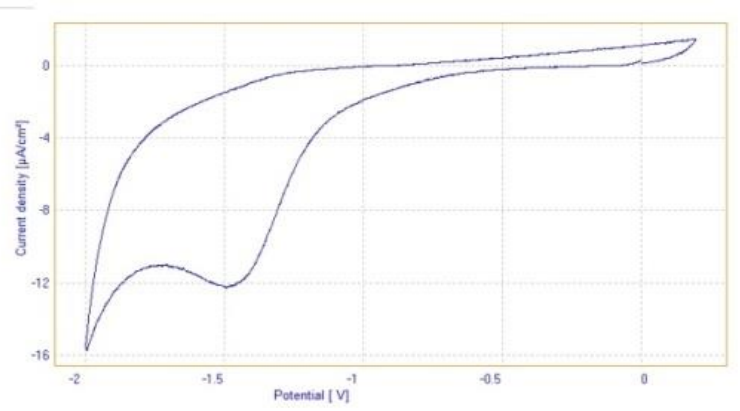

Scheme 6 . Electrochemical studies: Cyclic voltammogram of 5 a (10 $\mathrm{mM}$ ) performed at $22^{\circ} \mathrm{C}$ in dried and degassed THF containing $\mathrm{Bu}_{4} \mathrm{NPF}_{6}(100 \mathrm{mM})$ as the supporting

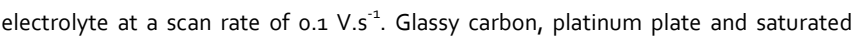
calomel were used respectively as working, counter and reference electrodes respectively.

Encouraged by these preliminary results, we first optimized the reaction conditions by screening the nature of the photocatalyst or the electron donor, by using different solvents and by modulating the reaction time or the ratio radical trap/hypercoordinated silicon (2/5a). Both DMF and $\mathrm{CH}_{3} \mathrm{CN}$ proved beneficial solvents for the reaction, while the reaction was less effective in THF (Table 1, entries 1, 2, 3 and 9). With respect to the sacrificial electron donor, changing DIPEA to triethylamine gave a comparable yield whereas no reaction was observed with Hantzch ester (Table 1, entries 2, 3 and 5). An extended irradiation time from $24 \mathrm{~h}$ to $48 \mathrm{~h}$ did not improve the photoreductive process (Table 1, entries 3 and 5). No more than $45 \%$ yield was reached with an excess of allylsulfone 2 (4 equiv, Table 1, entry 6). By contrast, if we consider allylsulfone $\mathbf{2}$ as the limiting substrate, addition of 2 or 3 equiv of organochlorosilane 5 a led 66 or $78 \%$ of 6 , respectively (Table $\mathbf{1}$, entries 7 and 8 ). An organic dye such as fluoroescein $(F)\left(E\left(F^{+} / F^{*}\right)=-1.61 \mathrm{~V}\right.$ vs $\left.S C E\right)$ was investigated as an alternative to $\operatorname{Ir}(\mathrm{ppy})_{3}$ but only $4 \%$ of 6 was obtained after $24 \mathrm{~h}$ of irradiation (Table 1, entry 10).

\begin{tabular}{|c|c|c|c|c|c|c|}
\hline Entry & Solvent & PCat & $\begin{array}{l}\text { Equiv } \\
(2 / 5 a)\end{array}$ & $\begin{array}{l}\text { Time } \\
\text { (h) }\end{array}$ & Donor & Yield $^{1}$ \\
\hline 1 & THF & $\operatorname{Ir}($ ppy)3 & $1.5 / 1$ & 24 & DIPEA & $24 \%$ \\
\hline 2 & DMF & $\operatorname{Ir}(\mathrm{ppy}) 3$ & $1.5 / 1$ & 24 & DIPEA & $35 \%$ \\
\hline 3 & DMF & $\operatorname{Ir}(\mathrm{ppy}) 3$ & $1.5 / 1$ & 24 & $\mathrm{Et}_{3} \mathrm{~N}$ & $36 \%$ \\
\hline 4 & DMF & $\operatorname{Ir}($ ppy)3 & $1.5 / 1$ & 24 & $\begin{array}{c}\text { Hantzch } \\
\text { ester }\end{array}$ & ०\% \\
\hline 5 & DMF & Ir(ppy)3 & $1.5 / 1$ & 48 & $\mathrm{Et}_{3} \mathrm{~N}$ & $37 \%$ \\
\hline 6 & DMF & $\operatorname{Ir}($ ppy)3 & $4 / 1$ & 24 & DIPEA & $45 \%$ \\
\hline 7 & DMF & $\operatorname{Ir}(\mathrm{ppy}) 3$ & $1 / 2$ & 24 & $\mathrm{Et}_{3} \mathrm{~N}$ & $66 \%$ \\
\hline 8 & DMF & $\operatorname{Ir}($ ppy)3 & $1 / 3$ & 24 & $\mathrm{Et}_{3} \mathrm{~N}$ & $78 \%$ \\
\hline 9 & $\mathrm{MeCN}$ & $\operatorname{Ir}(\mathrm{ppy})_{3}$ & $1.5 / 1$ & 24 & $\mathrm{Et}_{3} \mathrm{~N}$ & $32 \%$ \\
\hline 10 & $\mathrm{MeCN}$ & Fluorescein & $1.5 / 1$ & 24 & DIPEA & $4 \%$ \\
\hline 11 & DMF & - & $1 / 3$ & 24 & $\mathrm{Et}_{3} \mathrm{~N}$ & $33 \%$ \\
\hline 12 & DMF & Ir(ppy)3 & $1 / 3$ & 24 & - & $23 \%$ \\
\hline 13 & DMF & Ir(ppy)3 & $1 / 3$ & 24 & $\mathrm{Et}_{3} \mathrm{~N}$ & $0 \%$ \\
\hline
\end{tabular}

${ }^{1}$ NMR yield using TMOP as internal standard

Table 1. Optimisation of the reaction conditions and control reactions

Control experiments have been performed in order to secure the role of the photocatalyst and exclude an ionic process (Table 1, entries 11, 12 and 13). In the absence of photocatalyst, we ran the reaction under blue LEDs irradiation and allylsulfide 6 was obtained in 33\% yield. The formation of this small amount of 6 may arise from a photoinduced electron-transfer (PET) between $\mathrm{NEt}_{3}$ and the organosilane $5 \mathbf{a}$. No reaction occurred without blue LEDs activation. Only $23 \%$ for 6 was obtained when $\mathrm{NEt}_{3}$ was omitted. Even if we showed that the presence of the photocatalyst $\operatorname{Ir}(\mathrm{ppy})_{3}$ is required to reach a good yield, we tested the reactivity between pyridine-2-thiol and acceptor allylsulfone $\mathbf{2}$ under basic conditions. As expected, no trace of 6 was formed showing that the formation of the allylation adduct does not involve an ionic pathway and a radical process is likely to occur (Scheme 7). Of note, addition of $\operatorname{Ir}(\mathrm{ppy})_{3}$ (5 mol\%) to this mixture led to only $9 \%$ yield of 6 . From these last studies, we can deduce that most of thiopyridyl radicals were generated by reduction of silane $\mathbf{5}^{\mathbf{a}}$ leading to adduct $\mathbf{6}$, and not from the decomposition of $\mathbf{5}$ a. 


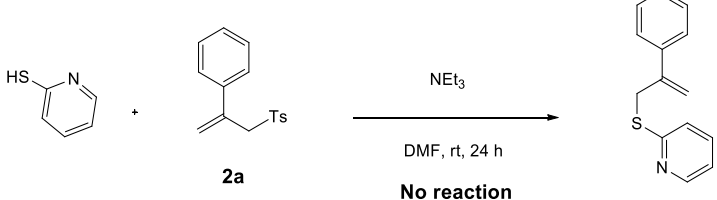

Scheme 7. Control experiment: reactivity between pyridine-2-thiol and acceptor allylsulfone 2 under basic conditions

In parallel, we examined the behavior of the commercially available aldrithiol $^{\mathrm{TM}}$ under the same photocatalytic conditions, as a potential source of thiopyridyl radical. Starting from 3 equivalents of this compound only a $18 \%$ yield of 6 was obtained compared to $78 \%$ from 5 a. This study showed all the interest of 5 a as an efficient precursor of thiopyridyl radical for synthetic transformations (Scheme 8).

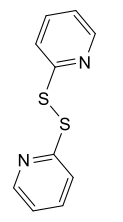

3 (equiv)

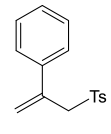

2 (1 equiv)

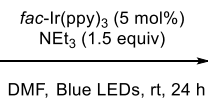

DMF, Blue LEDs, rt, 24

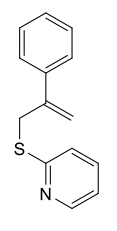

$618 \%$
Scheme 8. Photocatalytic reaction using aldrithiol ${ }^{\mathrm{TM}}$ as a radical precursor

Computational studies have been realized, namely at the B3LYP-D3/def2SV(P) level with the TURBOMOLE suite of programs. Upon reduction, it was showed that the SET process is occurring on the $\pi$ system of the pyridine moiety of $\mathbf{5}$ a (Scheme 9, lower part), in a similar manner to what have been observed with our biscatecholato silicates. ${ }^{18 a}$ If we compare the various BDEs of the substrates before and after oxidation, this reduction strongly weakens all Si-X $(X=C, S, C l)$ bonds. Particularly, the energy of the Si-S bond $(35 \mathrm{kcal} / \mathrm{mol}$ ) is lower than the one of the Si-C bond ( 46 $\mathrm{kcal} / \mathrm{mol})$ and the $\mathrm{Si}-\mathrm{Cl}$ bond $(63 \mathrm{kcal} / \mathrm{mol})$ and should favor the formation of the thiopyridyl radical (Scheme 9). We also investigated the nonhypercoordinated tetravalent species with two thiophenyl ligands, to compare directly the various BDE values with $\mathbf{5} \mathbf{a}$. This species is plotted on the right side of Scheme 9 . The reduction process is taking place on the thiophenyl moiety but the energy of the Si-S bond before reduction ( 76 $\mathrm{kcal} / \mathrm{mol})$ is higher than for the hypervalent silane $5 \mathbf{a}(66 \mathrm{kcal} / \mathrm{mol})$. This comparison shows also that whereas 5 a has a positive electron affinity $(10.35 \mathrm{kcal} / \mathrm{mol})$, this is not the case for $(\mathrm{PhS})_{2} \mathrm{Si}(\mathrm{Cl}) \mathrm{Ph}(-1.96 \mathrm{kcal} / \mathrm{mol})$, highlighting the ease of reduction of $5 \mathrm{a}$. As for $5 \mathrm{a}$, we also observed a small BDE of $27 \mathrm{kcal} / \mathrm{mol}$ after reduction. The other bonds are similarly affected by the reduction with the Si-Cl bond having a BDE of 64.5 $\mathrm{kcal} / \mathrm{mol}$ and the Si-Ph being at $40 \mathrm{kcal} / \mathrm{mol}$.
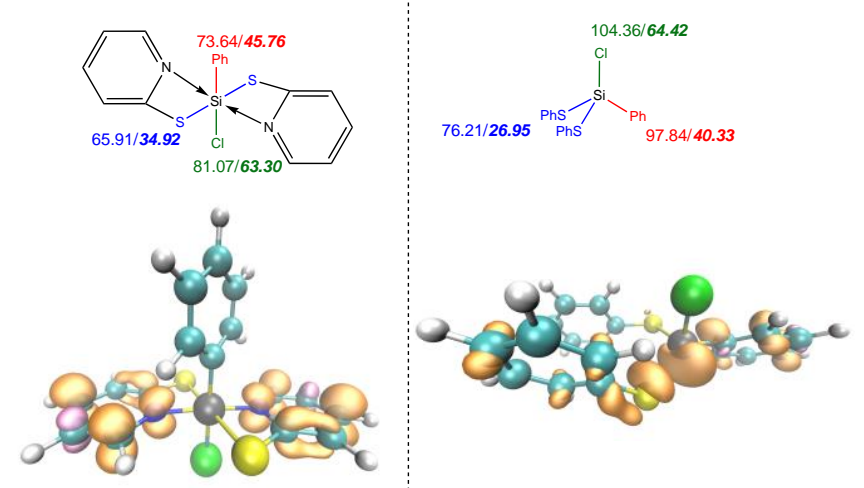

Scheme 9. Computational studies on 5 a and on phenylbis(phenylthiol)chlorosilane. Upper part : bond dissocation energies before and after reduction. Lower part: spin density isosurfaces

Based on these experimental studies, DFT calculations and in accordance with the literature, ${ }^{17}$ we can propose the following mechanism where the photoactivated catalyst under blue LEDs irradiation reduces hypercoodinated phenylchlorosilane $5^{a}$ at the pyridine moiety and promotes preferentially the homolytic cleavage of the Si-S bond between the thiopyridine ligand and silicon atom. The expelled thiopyridyl radical can be trapped by allylsulfone $\mathbf{2}$. The photocatalyst is regenerated by action of $\mathrm{NEt}_{3}$ (Scheme 10). It should be mentioned that formation of 6 involved sequential addition of the thiopyridine radical, generation of the transient radical intermediate $\mathbf{A}$ and homolytic fragmentation of the C-Ts bond. We were surprised by the fact that intermediate $\mathbf{A}$ is more prone to give the homolytic fragmentation of the C-Ts bond rather than the reversible extrusion of the thiopyridine radical moiety. It is indeed known in the literature that a thiophenyl radical is a good leaving group, presumably better than the phenysulfonyl one. ${ }^{24}$ To rationalize the observed selectivity, DFT calculations of $\beta$-fragmentation processes on intermediate $\mathbf{A}$ and on an analogous intermediate $\left(\mathbf{A}^{\prime}\right)$ where the pyridine moiety is replaced by a phenyl were thus conducted, at the same level of theory (namely $B_{3} L Y P-D_{3} /$ def $\left._{2}-S V(P)\right)$. On $A^{\prime}$, calculations indicate that departure of the tosyl radical is slightly favored over the thiophenyl radical fragmentation (barriers of $8.4 \mathrm{kcal} / \mathrm{mol}$ versus $9.3 \mathrm{kcal} . \mathrm{mol}$ ). But the situation is totally different in the case of intermediate $\mathbf{A}$ : while the tosyl radical departure remains in the same energetic range with a barrier of 9 $\mathrm{kcal} / \mathrm{mol}$, the thiopyridyl radical extrusion proves to be unfeasible with an always increasing potential energy surface (see Figure 1), reaching value over $18 \mathrm{kcal} / \mathrm{mol}$. It turns out that the thiopyridyl radical is particularly unstable and observation of the geometry highlights that this radical is trying to establish non-covalent interactions between the nitrogen of the pyridine moiety and the homobenzylic C-H to stabilize itself. Therefore, the mechanism proposed in Scheme $\mathbf{1 0}$ is supported by this computational analysis. 


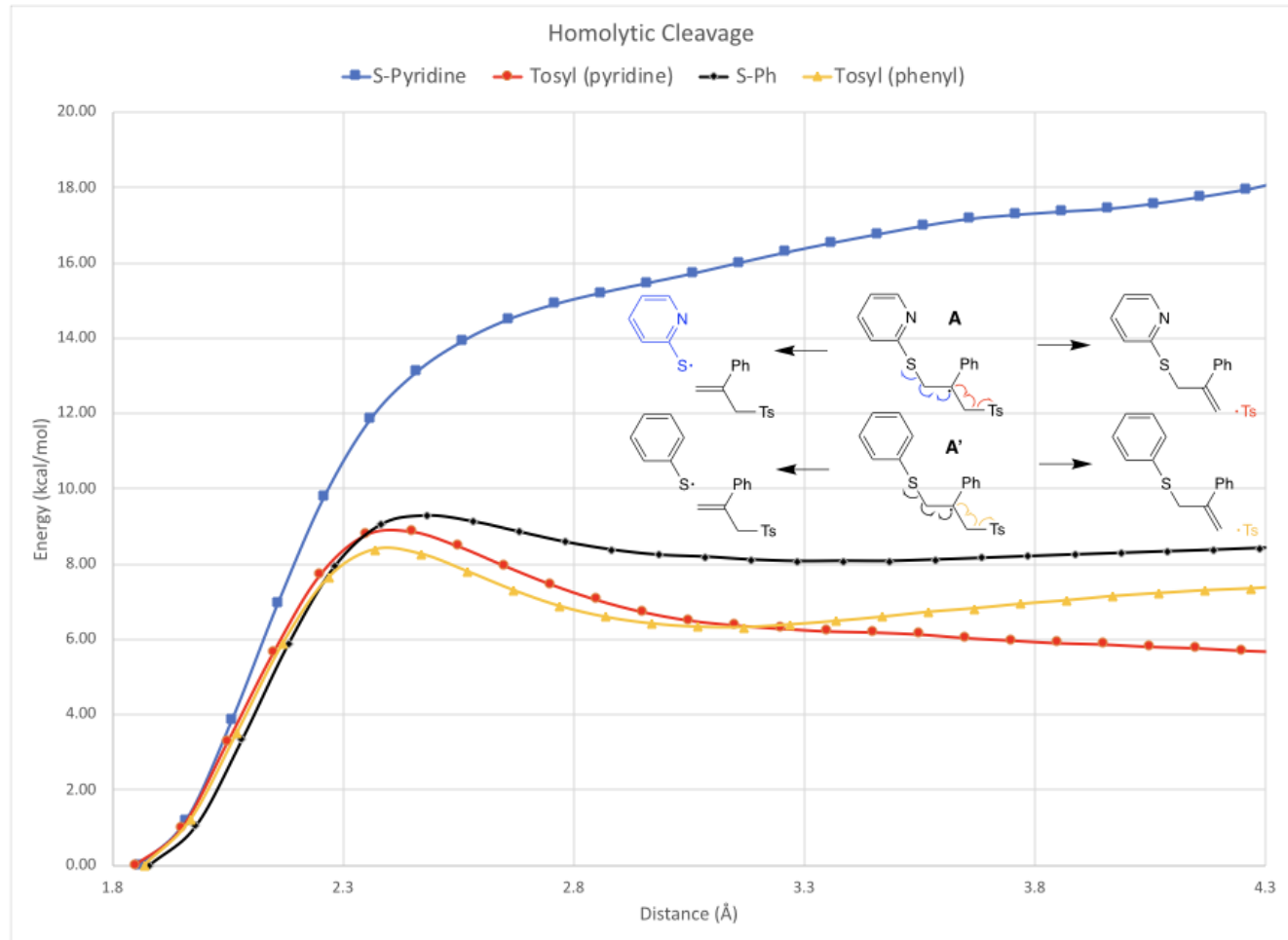

Figure 1. Calculated $\beta$-fragmentation processes for intermediate $\mathbf{A}$ and $\mathbf{A}^{\prime}$, at the $B_{3} L Y P-D_{3} /$ def2-SV(P) level.

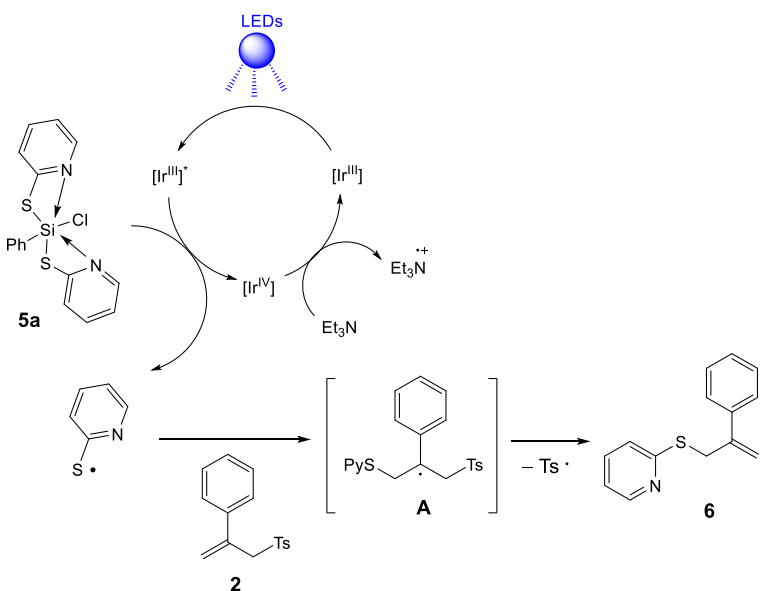

Scheme 10. Proposed mechanism for the formation of 6

Due to the weakness of the Si-S bond and its ability to generate thiyl radicals under reductive conditions, we compared the reactivity of our previous system (5a) with the non-hypercoordinated tetravalent phenylsilane bearing three thiophenyl ligands 7 (Scheme 11). This one was synthesized from phenylsilane and thiophenol according to the literature procedure. ${ }^{25}$ Its reduction potential was then measured. A value of $-1.75 \mathrm{~V}$ vs SCE was obtained which appears to be lower than the reduction potential of $\mathbf{5 a}$ (Scheme 12). This difference of potential may explain why no allyllation adduct 6 was formed from 5 a under the same reductive conditions (Scheme 11).
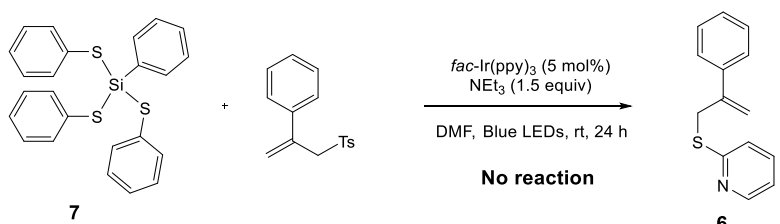

Scheme 11. Photocatalytic reaction using phenyltris(phenylthio)silane as a radical precursor

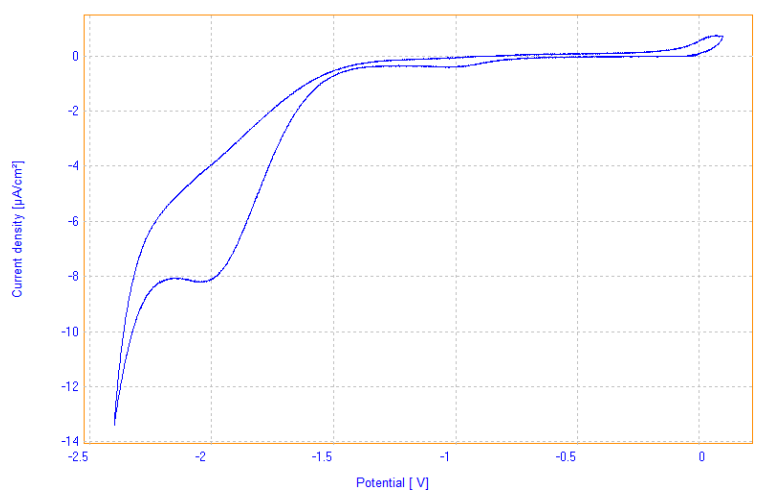

Scheme 12. Electrochemical studies: cyclic voltammetry of 7 (10 $\mathrm{mM}$ ) performed at $22^{\circ} \mathrm{C}$ in dried and degassed THF containing $\mathrm{Bu}_{4} \mathrm{NPF}_{6}(100 \mathrm{mM})$ as the supporting electrolyte at a scan rate of 0.05 V.s ${ }^{-1}$. Glassy carbon, platinum plate and saturated calomel were used respectively as working, counter and reference electrodes respectively. 
We next evaluated the reactivity of the hypercoodinated methylchlorosilane $\mathbf{5} \mathbf{b}$ under photocatalytic reductive conditions. We first prepared it by using the same procedure as for 5 a starting from methyltrichlorosilane and then we measured its reduction potential, which was estimated by $\mathrm{CV}$ at about $-1.37 \mathrm{~V}$ (vs SCE). This value still suggests that the photo-excited photocatalyst $f a c-\operatorname{Ir}(\mathrm{ppy})_{3}(\mathrm{E} \operatorname{Ir}(\mathrm{IV}) / \operatorname{Ir}(\mathrm{III}) *=-1.7 \mathrm{~V}$ vs SCE) can reduce this substrate. Treatment of $5 \mathbf{b}$ (3 equiv) with $\mathbf{2}$ ( 1 equiv) in the presence of $f a c-\operatorname{Ir}(\mathrm{ppy})_{3}(5 \mathrm{~mol} \%)$ and $\mathrm{Et}_{3} \mathrm{~N}$ (1.5 equiv) in DMF under blue LEDs irradiation gave 6 in 31\% yield (Scheme 13). It should be noted that no addition of the methyl group was observed. For comparison, its benzyl analog $5 \mathrm{c}$ has also been investigated. This compound was prepared in-situ from benzyltrichlorosilane but could not be isolated. Nevertheless, the photocatalytic reaction was carried on the crude reaction mixture and the allylsulfide 6 was obtained in $15 \%$ yield as the only product.

From those experiments, only the thiopyridyl radical was formed as evidenced by trapping experiments with allylsulfone 2 . The phenyl derivative was revealed to be the most reactive and provided the best yield in allylsulfide 6 . Interestingly, formation of phenyl, methyl or benzyl radical was never observed in these studies.
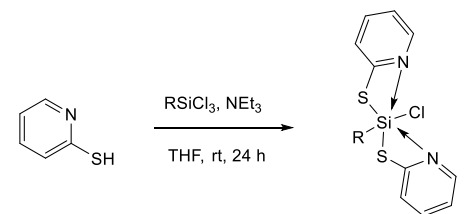

5b $\mathrm{R}=\mathrm{Me}$ in DMF, $9 \%$ $5 c \mathrm{R}=\mathrm{Bn}$ in $\mathrm{THF}$, not isolated
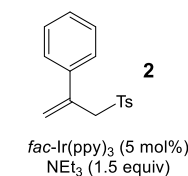

DMF or THF Blue LEDs, rt, $24 \mathrm{~h}$

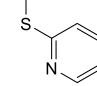

$624 \%$ $15 \%$
Scheme $\mathbf{1 3}$. Synthesis of pentavalent silicon compounds $\mathbf{5}$ b and $\mathbf{5} \mathbf{c}$, using N, Spyridine-2-thiolato ligand followed by their reactivity in the presence of allylsulfone $\mathbf{2}$ under visible-light photoreductive conditions. Formation of allylsulfide 6 .

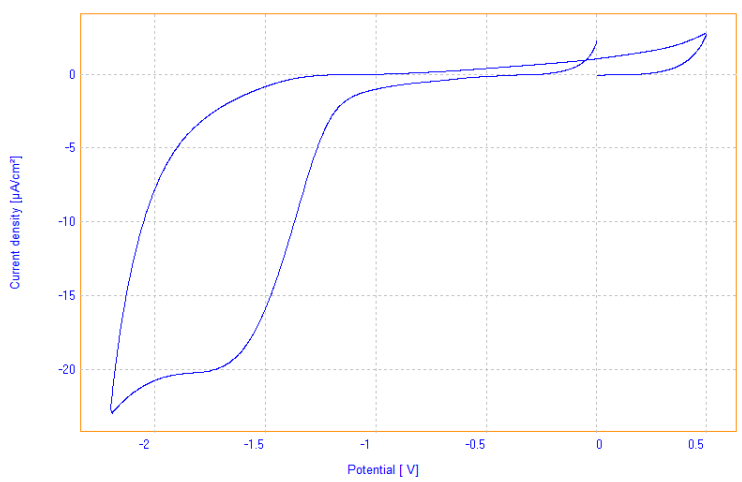

Scheme 14. Electrochemical studies: Cyclic voltammogram of $\mathbf{5 b}$ (10 $\mathrm{mM}$ ) performed at $22^{\circ} \mathrm{C}$ in dried and degassed THF containing $\mathrm{Bu}_{4} \mathrm{NPF}_{6}(100 \mathrm{mM})$ as the supporting electrolyte at a scan rate of 0.1 V.s. ${ }^{-1}$. Glassy carbon, platinum plate and saturated calomel were used respectively as working, counter and reference electrodes respectively.
Finally, we looked at the photoreduction of the highly electron deficient silylium derivative $5 \mathrm{~d}$ readily obtained by action of TMSI on the corresponding phenylchlorosilane $\mathbf{5 a}^{21}$ Under the optimized photocatalytic conditions determined for $5 \mathbf{a}, 5 \mathrm{~d}$ provided $\mathbf{6}$ as the sole product with the same yield as $\mathbf{5 a}$. This result showed that silylium ${ }_{5} \mathbf{d}$ can be reduced as efficiently as phenylchlorosilane $\mathbf{5} \mathbf{a}$ and participate in radical reactions (Scheme 15).

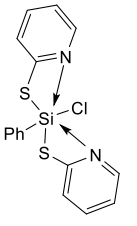

$5 a$

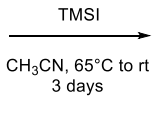

(2)

5d $24 \%$

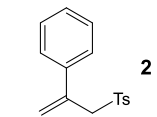

fac- $\operatorname{lr}(\mathrm{ppy})_{3}(5 \mathrm{~mol} \%)$ $\mathrm{NEt}_{3}(1.5$ equiv) DMF, Blue LEDs, rt, 24

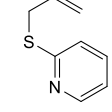

$675 \%$
Scheme 15. Synthesis of silylium derivative $5 \mathbf{d}$, using N,S-pyridine-2-thiolato ligand followed by their reactivity in the presence of allylsulfone $\mathbf{2}$ under visible-light photoreductive conditions. Formation of allylsulfide 6 .

Interestingly, as the thiopyridine moiety is encountered in various bioactive molecules (Scheme 16), ${ }^{26}$ efficient reactions allowing the synthesis of these compounds in mild conditions remains interesting. ${ }^{27}$

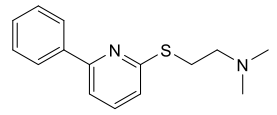

High affinity to h5HT7 ligands

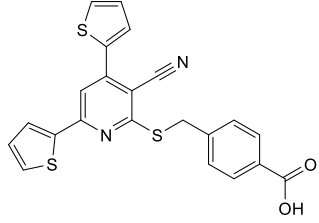

Inhibitor of Bacterial Enoyl-Acyl Carrier Protein Reductase
Scheme 16. Bioactive molecules containing a thiopyridine scaffold

\section{Conclusions}

In conclusion, we have demonstrated that the modification of the ligands of hexacoordinated chlorosilane derivatives can efficiently modulate their reactivity towards photoreductive conditions. By using a thiopyridine ligand, the corresponding thiyl radical has been liberated and efficiently trapped by an allylsulfone as an acceptor. Even if these radicals could be formed through the oxidation of pyridine thiolate like phenyl thiolate, ${ }^{28}$ no methodology has already been reported by using a reductive pathway. Experiments are currently ongoing in our laboratory for the formation of carbon-centered radicals by photoreduction of other types of hypercoordinated silicon species. 


\section{Experimental Section}

To a Schlenk flask was added the silicon complex $5 \mathrm{a}-\mathrm{d}, \operatorname{Ir}(\mathrm{ppy}) 3$ (5 mol \%), and allyl sulfone 2 . The degassed solvent ( $0.1 \mathrm{~mol} / \mathrm{L}$ or $0.067 \mathrm{~mol} / \mathrm{L}$ ) was then introduced followed by the amine (1.5 equiv) and the reaction mixture was irradiated with blue LEDs $(470 \mathrm{~nm})$ at room temperature for $24 \mathrm{~h}$ under an argon atmosphere. The reaction mixture was diluted with diethyl ether, washed with water (2 times), dried over $\mathrm{MgSO}_{4}$ and evaporated under reduced pressure. The crude residue was purified by flash chromatography.

\section{Supplementary Material ((optional))}

Supporting information for this article is available on the WWW under http://dx.doi.org/10.1002/MS-number. ((Please delete this text if not appropriate))

\section{Acknowledgements}

We thank Sorbonne University, CNRS, ANR-17-CE07-0018 HyperSilight (PhD grant to E.L.).

\section{References}

[1] a) S. E. Thomas, 'Organic Synthesis: The Roles of Boron and Silicon', Oxford Chemistry Primers series, 1991; b) G. R. Jones, Y. Landais, 'The oxidation of the carbon-silicon bond', Tetrahedron 1996, 52, 7599-7662.

[2] a) C. Chatgilialoglu, 'Organosilanes as radical-based reducing agents in synthesis', Acc. Chem. Res. 1992, 25, 188-194; b) C. Chatgilialoglu, 'Structural and Chemical Properties of Silyl Radicals', Chem. Rev. 1995, 95, 1229-1251; c) C. Chatgilialoglu, C. H. Schiesser, 'Silyl radicals in The Chemistry of Organic Silicon Compounds', Vol. 3, Z. Rappoport, Y. Apeloig Eds., Wiley, Chichester, 2001, pp. 341-390; d) Y. Landais, 'Silyl Radicals in Science of Synthesis', D. Bellus, S. Ley, R. Noyori, B. Trost, Eds. G. Thieme, 2013, Vol. 26, chap. 4.

[3] For selected exemples of hydrosilylation under photocatalytic conditions : a) H. Orareya, D. Dondi, D. Ravelli, M. Fagnoni, 'Decatungstate-Photocatalyzed $\mathrm{Si}-\mathrm{H} / \mathrm{C}-\mathrm{H}$ Activation in Silyl Hydrides: Hydrosilylation of Electron-Poor Alkenes', ChemCatChem. 2015, 7, 3350-3357; b) R. Zhou, Y. Goh, H. Liu, H. Tao, L. Li, J. Wu, 'Visible-Light-Mediated Metal-Free Hydrosilylation of Alkenes through Selective Hydrogen Atom Transfer for Si-H Activation', Angew. Chem. Int. Ed. 2017, 56, 16621-16625.

[4] a) C. Chatgilialoglu, J. Lalevée, 'Recent Applications of the (TMS) ${ }_{3} \mathrm{SiH}$ RadicalBased Reagent', Molecules 2012, 17, 527-555. b) C. Chatgilialoglu, C. Ferreri, Y. Landais, V. I. Timokhin, 'Thirty Years of (TMS)3 3 SiH: A Milestone in RadicalBased Synthetic Chemistry Chem. Rev. 2018, 118, 6516-6572.

[5] B. P. Roberts, 'Polarity-reversal catalysis of hydrogen-atom abstraction reactions: concepts and applications in organic chemistry', Chem. Soc. Rev. 1999, 28, 25-35

[6] A. Matsumoto, Y. Ito, 'New Generation of Organosilyl Radicals by Photochemically Induced Homolytic Cleavage of Silicon-Boron Bonds', J. Org Chem. 2000, 65, 5707-5711.
[7] R. T. Smith, X. Zhang, J. A. Rincón, J. Aregas, C. Mateos, M. Barberis, S. García-Cerrada, O. de Frutos, D. W. C. MacMillan, 'MetallaphotoredoxCatalyzed Cross-Electrophile Csp ${ }^{3}-\mathrm{Csp}^{3}$ Couplingof Aliphatic Bromides', J. Am. Chem. Soc. 2018, 140, 17433-17438.

[8] a) R. J. P. Corriu, R. Perz, C. Réye, 'Activation of silicon-hydrogen, siliconoxygen, silicon-nitrogen bonds in heterogenous phase: Some new methods in organic synthesis', Tetrahedron 1983, 39, 999-1009; b) C. Chult, R. J. P. Corriu, C. Reye, J. C. Young, 'Reactivity of Penta- and Hexacoordinate Silicon Compounds and Their Role as Reaction Intermediates', Chem. Rev. 1993, 93, $1371-1448$; c) R. R. Holmes, 'Comparison of Phosphorus and Silicon: Hypervalency, Stereochemistry and Reactivity', Chem. Rev. 1996, 96, 927950 ; d) S. Rendler, M. Oestreich, 'Hypervalent Silicon as a Reactive Site in Selective Bond-Forming Processes', Synthesis. 2005, 11, 1727-1747.

[9] a) M. Silvi, C. Verrier, Y. P. Rey, L. Buzzetti, P. Melchiorre, 'Visible-light excitation of iminium ions enables the enantioselective catalytic $\beta$-alkylation of enals', Nat.Chem. 2017, 9, 868-873; b) M. Uygur, T. Danelzik, O. GarciaMancheño, 'Metal-free desilylative C-C bond formation by visible-light photoredox catalysis', Chem. Commun. 2019, 55, 2980-2983.

[10] a) G. Gutenberger, E. Steckhan, S. Blechert, ' $\alpha$-Silyl Ethers as Hydroxymethyl Anion Equivalents in Photoinduced Radical Electron Transfer Additions', Angew. Chem. Int. Ed. 1998, 37, 660-662; b) M. K. Jackl, L. Legnani, B. Morandi, J. W. Bode, 'Continuous Flow Synthesis of Morpholines and Oxazepanes with Silicon Amine Protocol (SLAP) Reagents and Lewis Acids Facilitated Photoredox Catalysis', Org. Lett. 2017, 19, 4696-4699; c) N. Khatun, M. J. Kim, S. K. Woo,'Visible-Light Photoredox-Catalyzed Hydroalkoxymethylation of Activated Alkenes Using $\alpha$-Silyl Ethers as Alkoxymethyl Radical Equivalents', Org. Lett. 2018, 20, 6239-6243.

[11] L. Capaldo, R. Riccardi, D. Ravelli, M. Fagnoni, 'Acyl Radicals from Acylsilanes: Photoredox-Catalyzed Synthesis of Unsymmetrical Ketones', ACS Catal. 2018, 8, 304-309

[12] a) J. I. Yoshida, K. Tamao, T. Kakui, A. Kurita, M. Murata, K. Yamada, M. Kumada, 'Organofluorosilicates in organic synthesis. Copper (II).oxidation of Organopentafluorosilicates', Organometallics. 1982, 1, 369-380; b) For a related work: T. Wang, D.-H. Wang, 'Potassium Alkylpentafluorosilicates, a Practical Primary Alkyl Radical Precursor, in the C-1 Alkylation of Tetrahydroisoquinolines' Org. Lett. 2019, 21, 3981-3985.

[13] a) Y. Nishigaichi, A. Suzuki, A. Takuwa, 'Remarkable enhancement of photoallylation of aromatic carbonyl compounds with a hypervalent allylsilicon reagent by donor molecules', Tetrahedron Lett. 2007, 48, 211-214; b) D. Matsuoka, Y. Nishigaishi, 'Photosubstitution of Dicyanoarenes by Hypervalent Allylsilicon Reagents via Photoinduced Electron Transfer', Chem. Lett. 2014, 43,559-561.

[14] C. L. Frye, 'Pentacoordinate Silicon Derivatives. II. Salts of Bis(o-arylenedioxy) organosiliconic Acids', J. Am. Chem. Soc. 1964, 86, 3170-3171.

[15] G. Sorin, R. Martinez Mallorquin, Y. Contie, A. Baralle, M. Malacria, J.-P. Goddard, L. Fensterbank, 'Oxidation of Alkyl Trifluoroborates: An Opportunity for Tin-Free Radical Chemistry', Angew. Chem. Int. Ed. 2010, 49, 8721-8723.

[16] a) V. Corcé, L.-M. Chamoreau, E. Derat, J.-P. Goddard,C. Ollivier and L. Fensterbank, 'Silicates as Latent Alkyl Radical Precursors: Visible-Light Photocatalytic Oxidation of Hypervalent Bis-Catecholato Silicon Compounds', Angew. Chem. Int. Ed., 2015, 54, 11414-11418; b) M. Jouffroy, D. N. Primer, G. A. Molander, 'Base-Free Photoredox/Nickel Dual-Catalytic Cross-Coupling of Ammonium Alkylsilicate', J. Am. Chem. Soc. 2016, 138, 475478. 
[17] For selected references, see: a) J. M. R. Narayanam, C. R. J. Stephenson, 'Visible light photoredox catalysis: applications in organic synthesis', Chem. Soc. Rev. 2011, 40, 102-103; b) C. K. Prier, D. A. Rankic, D. W. C. MacMillan, 'Visible light photoredox catalysis with transition metal complexes: applications in organic synthesis', Chem. Rev. 2013, 113, 5322-5363; C) J. Xuan, L.-O. Lu, J.-R. Chen, W.-J. Xiao, 'Visble-Light Driven Photoredox Catalysis in the Construction of Carbocyclic and Heterocyclic Ring Systems', Eur. J. Org. Chem. 2013, 30, 6755-6770; d) T. Koike, M. Akita, 'Visible-light radical reaction designed by Ru- and Ir-based photoredox catalysis', Inorg. Chem. Front. 2014, 1, 562-576; e) M. H. Shaw, J. Twilton, D. W. C MacMillan, 'Photoredox Catalysis in Organic Chemistry', J. Org. Chem. 2016, 81, 6898-6926; f) J. Xuan, Z.-G. Zang, W.-J. Xiao, 'Visible-light-induced Decarboxilative Functionalization of Carboxylic Acids and Their Derivatives', Angew. Chem. Int. Ed. 2015, 54, 15632-15641; g) I. Ghosh, L. Marzo, A. Das, S. Rizwan, B. König, 'Visible Light Mediated Photoredox Catalytic Arylation Reactions', Acc. Chem. Res. 2016, 49, 1566-1577; h) J.-R. Chen, X.-O. Hu, L.-O. Lu, W.-J. Xiao, 'Exploration of Visible-Light Photocatalysis in Heterocycle synthesis and Functionalization: Reaction Design and Beyond', Acc. Chem. Res. 2016, 49, 1911-1923; i) J.-P. Goddard, C. Ollivier, L. Fensterbank, 'Photoredox Catalysis in Organic Chemistry', Acc. Chem. Res. 2016, 49, 1924-1936; j) K. Nakajima, Y. Miyake, Y. Nishibayashi, 'Photoredox-Mediated Routes to Radicals: The Value of Catalytic Radical Generation in Synthetic Methods Development', Acc. Chem. Res. 2016, 49, 1946-1956; k) T. P. Yoon, 'Photochemical Stereocontrol Using Tandem Photoredox-Chiral Lewis Acid Catalysis', Acc. Chem. Res. 2016, 49, 2307-2315; I) J.-R. Chen, X.-O. Hu, L.-O.- Lu, W.-J. Xiao, 'Visible light photoredox-controlled reactions of $\mathrm{N}$-radicals and radical-ion', Chem. Soc. Rev. 2016, 45, 2044-2056; m) N. A. Romero, D. A. Nicewicz, 'Organic Photoredox Catalysis', Chem. Rev. 2016, 116, 10075-10166; n) S. Poplata, A. Tröster, Y-Q. Zou, T. Bach, 'Recent advances in the Synthesis of Cyclobutanes by Olefin [2 + 2] Photocycloaddition Reactions', Chem. Rev. 2016, 116, 9748-9815; 0) D. Ravelli, S. Proti M. Fagnoni, 'Carbon-Carbon Bond Forming Reactions via Photogenerated Intermdiates', Chem. Rev. 2016, 116, 9850-9913; p) J. K. Matsui, S. B. Lang, D. R. Heitz, G. A. Molander, 'Photoredox-Mediated Routes to Radicals: The value of Catalytic Radical Generation in Synthetic Methods Development', ACS Catal. 2017, 7, 25632575; q) L. Marzo, S. K. Pagire, O. Reiser, B. König, 'Visible-Light Photocatalysis: Does it Make a Difference in Organic Synthesis?', Angew. Chem. Int. Ed. 2018, 57, 10034-10072.

[18] a) C. Lévêque, L. Chennenberg, V. Corcé, J.-P. Goddard, C. Ollivier and L. Fensterbank, 'Primary alkyl bis-catecholato silicates in dual photoredox/nickel catalysis: aryl- and heteroaryl-alkyl cross coupling reactions', Org. Chem. Front. 2016, 3, 462; b) C. Lévêque, L. Chenneberg, V. Corcé, C. Ollivier, L. Fensterbank, 'Organic photoredox catalysis for the oxidation of silicates: applications in radical synthesis and dual catalysis', Chem. Comm. 2016,52, 9877-9880; c) C. Lévêque, V. Corcé, L. Chenneberg, C. Ollivier, L. Fensterbank, 'Photoredox/Nickel Dual Catalysis for the $\mathrm{C}\left(\mathrm{sp}^{3}\right)-\mathrm{C}\left(\mathrm{Sp}^{3}\right)$ CrossCoupling of Alkylsilicates with Alkyl Halides', Eur. J. Org. Chem. 2017, 21182121; d) A. Cartier, E. Levernier, V. Corcé, T. Fukuyama, A.-L. Dhimane, C. Ollivier, I. Ryu, L. Fensterbank, 'Carbonylation of Alkyl radicals Derived from Organosilicates through Visible-Light Photoredox Catalysis', Angew. Chem. Int. Ed. 2019, 58, 1789-1793; e) E. Levernier, V. Corcé, L.-M. Rakotoarison, A. Smith, M. Zhang, S. Ognier, M. Tatoulian, C. Ollivier, L. Fensterbank, 'CrossCoupling of alkylsilicates with acyl chlorides via photoredox/nickel dual catalysis: a new synthesis method for ketones', Org. Chem. Front. 2019, 6 , 1378-1382.
[19] E. Wächtler, A. Kämpfe, K. Krupinksi, D. Gerlach, E. Kroke, E. Brendler, J. Wägler, 'New Insights into Hexacoordinated Silicon Complexes with 8Oxyquinolinato Ligands: 1,3-Shift of Si-Bound Hydrocarbyl Substituents and the Influence of Si-Bound Halides on the 8-Oxyquinolinate Coordination Features', Z. Naturforsch. 2014, 69b, 1402-1418.

[20] J. Wei $\beta$, B. Theis, S. Metz, C. Burschka, C. F. Guerra, .F. M. Bickelhaupt, R. Tacke, 'Neutral Pentacoordinate Halogeno- and Pseudohalogenosilicon(IV) Complexes with a Tridentate Dianionic O, N, O or N,N,O Ligand: Synthesis and Structural Characterization in the Solid State and in Solution', Eur. J. Inorg. Chem. 2012, 3216-3228.

[21] J. A. Baus, C. Burschka, R. Bertemann, C. F. Guerra, F. M. Bickelhaupt, R. Tacke, 'Neutral Six-Coordinate and Cationic Five-Coordinate Silicon (IV)Complexes with Two Bidentate Monoanionic N,S-Pyridine-2-thiolato(-) Ligands', Inorg. Chem. 2013, 52, 10664-10676.

[22] F. Speck, D. Rombach, H. A. Wagenknecht, 'N-Arylphenothiazines as strong donors for photoredox catalysis - pushing the frontiers of nucleophilic addition of alcohols to alkenes', Beilstein J. Org. Chem. 2019, 15, 52-59.

[23] B. Braïda, S. Hazebroucq, P. C. Hiberty, 'Methyl Substituent Effects in $\left[\mathrm{H}_{n} \mathrm{X}: \mathrm{XH}_{n}\right]^{+}$Three-Electron-Bonded Radical Cations $(\mathrm{X}=\mathrm{F}, \mathrm{O}, \mathrm{N}, \mathrm{Cl}, \mathrm{S}, \mathrm{P} ; n=$ 1-3). An ab Initio Theoretical Study', J. Am. Chem. Soc. 2002, 124, 2371-2378.

[24] a) P. J. Wagner, J. H. Sedon, M. J. Lindstrom, 'Rates of Radical $\beta$-Cleavage in Photogenerated Diradicals', J. Am. Chem. Soc. 1978, 100, 2579-2580. b) V. I. Timokhin, S. Gastaldi, M. P. Bertrand, C. Chatgilialoglu, 'Rate Constants for the $\beta$-Elimination of Tosyl Radical from a Variety of Substituted CarbonCentered Radicals', J. Org. Chem. 2003, 68, 3532-3537.

[25] J. B. Baruah, K. Osakada, T. Yamamoto, 'Polycondensation of Diarylsilanes with Aromatic Dithiols and the Model Reaction Involving $\mathrm{RhCl}\left(\mathrm{PPh}_{3}\right)_{3}$ Catalyzed Si-S Bond Formation', Organometallics 1996, 15, 456-459.

[26] a) C. G. Thomson, M. S. Beer, N. R. Curtis, H. J. Diggle, E. Handford, J. J. Kulagowski, 'Thiazoles and thiopyridines: novel series of high affinity $\mathrm{h}_{5} \mathrm{HT}_{7}$ ligands', Bioorg. Med. Chem. Lett. 2004, 14, 677-68o; b) L. L. Ling, J. Xian, S. Ali, B. Geng, J. Fuan, D. M. Mills, A. C. Arvanites, H. Orgueira, M. A. Aswhell, G. Carmel, Y. Xiang, D. T. Moir, 'Identification and Characterization of Inhibitors of Bacterial Enoyl-Acyl Carrier Protein Reductase', Antimicrob. Agents Chemother. 2004, 48, 1541-1547.

[27] D. H. R. Barton, D. Crich, G. Kretzschmar, 'The Invention of New Radical Chain Reactions. Part 9. Further Radical Chemistry of Thiohydroxamic Esters; Formation of Carbon-Carbon Bonds', J. Chem. Soc., Perkin Trans. 1 1986, 3953.

[28] For a recent review: A. V. Bordoni, M. V. Lombardo, A. Wolosiuk, 'Photochemical radical thiol-ene click-based methodologies for silica and transition metal oxides materials chemical modification: a mini-review', RSC Adv. 2016, 6, 77410-77426. 


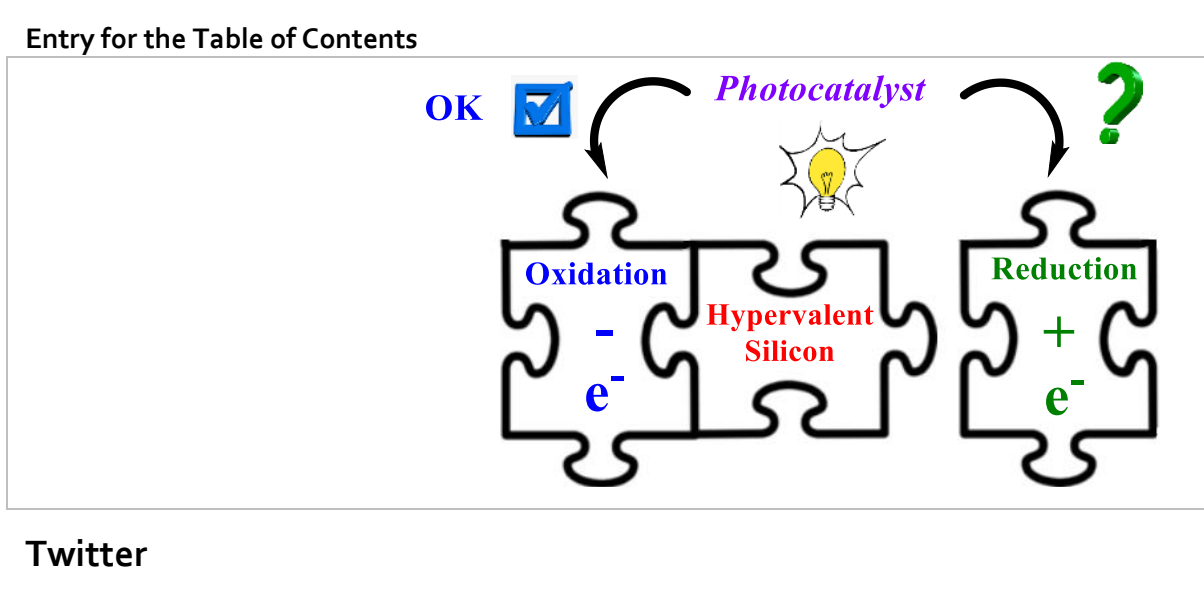

Twitter
The tweet te 


\section{Towards Visible-Light Photocatalytic Reduction of Hypercoordinated Silicon Species}

Etienne Levernier ${ }^{\mathrm{a}}$, Christophe Lévêque ${ }^{\mathrm{a}}$, Etienne Derat ${ }^{\mathrm{a}}$, Cyril Ollivier $^{\mathrm{a} *}$ and Louis Fensterbank ${ }^{\mathrm{a} *}$

${ }^{a}$ Sorbonne Université, CNRS, Institut Parisien de Chimie Moléculaire,4 Place Jussieu, CC 229, F-75252 Paris Cedex 05, France E-mail: louis.fensterbank@ sorbonne-universite.fr, cyril.ollivier@sorbonne-universite.fr.

\section{Table of content}

I. General informations 2

II. General procedures 3

III. Electrochemical measurement 9

V. Coordinates of calculated species $\quad 12$

VI. $\quad{ }^{1} \mathrm{H},{ }^{13} \mathrm{C}$ NMR spectra $\quad 15$ 


\section{General informations}

Unless otherwise noted, reactions were carried out under an argon atmosphere in oven-dried glassware. THF, acetonitrile and diethyl ether were distillated over sodium/benzophenone, triethylamine over potassium hydroxide. Reagents and chemicals were purchased from commercial sources and used as received. Infrared (IR) spectra were recorded on a Bruker Tensor 27 (ATR diamond) spectrophotometer. ${ }^{1} \mathrm{H},{ }^{13} \mathrm{C}$ NMR spectra were recorded at room temperature at 400,377 and $100 \mathrm{MHz}$ respectively, on a Bruker AVANCE 400 spectrometer. Chemical shifts $(\delta)$ are reported in ppm and coupling constants $(J)$ are given in Hertz $(\mathrm{Hz})$. Abbreviations used for peak multiplicity are: $\mathrm{s}$ (singlet); bs (broad singlet); d (doublet); t (triplet); q (quartet); quint (quintet); sept (septet); m (multiplet). Thin layer chromatographies (TLC) were performed on Merck silica gel 60 F 254 and revealed with a UV lamp $(\lambda=254 \mathrm{~nm})$ and $\mathrm{KMnO} 4$ staining. Flash Column Chromatographies were conducted on silica Geduran ${ }^{\circledR}$ Si $60 \AA(40-63 \mu \mathrm{m})$. High resolution mass spectrometries were performed on a microTOF (ESI). 


\section{General procedures}

\section{Synthesis of the silicon complexes}

All these complexes were previously described by Tacke's, Yamamoto's or Wagler's group.

\section{$8,8^{\prime}-(($ chloro(phenyl)silanediyl)bis(oxy))diquinoline (1a)}

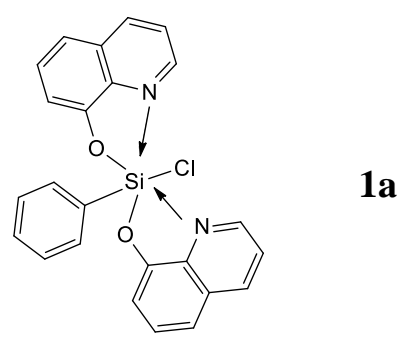

To a dried Schlenck tube with 8-Oxyquinoline (2.00 g, $13.7 \mathrm{mmol})$ and triethylamine (2.89 $\mathrm{mL}, 20.7$ $\mathrm{mmol})$ in THF $(50 \mathrm{~mL})$ was added dropwise chlorotrimethylsilane $(2.07 \mathrm{~mL}, 16.3 \mathrm{mmol})$ at $0^{\circ} \mathrm{C}$. The triethylammonium salt was filtered off and washed with THF $(2 \times 10 \mathrm{~mL})$. The residue was dissolved in chloroform $(30 \mathrm{~mL})$ and cooled to $0^{\circ} \mathrm{C}$. At this temperature, phenyltrichlorosilane $(1.1 \mathrm{~mL}, 6.86$ $\mathrm{mmol}$ ) was added and the solution was stored at room temperature. The yellow crystalline product was filtered off, washed with chloroform $(2 \times 5 \mathrm{~mL})$ and dried in vacuo to afford 8,8'((chloro(phenyl)silanediyl)bis(oxy))diquinoline (1a) (2.1 g, 71\%). No analysis could be done due to the very poor solubility of this compound.

\section{2-chloro-4,6-dimethyl-2-phenylbenzo[d][1,3,6,2]dioxazasilonine (3)}

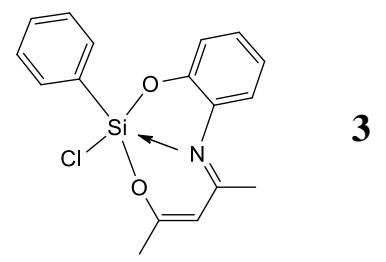

Triethylamine $(40 \mathrm{mmol}, 5.6 \mathrm{~mL})$ and trichlorophenylsilane $(20 \mathrm{mmol}, 3.2 \mathrm{~mL})$ were added at $0^{\circ} \mathrm{C}$ to a stirred suspension of 2-((E)-((Z)-4-hydroxypent-3-en-2-ylidene)amino)phenol (20.0 mmol, $3.82 \mathrm{~g}$ ) in tetrahydrofuran $(60 \mathrm{~mL})$. After that, the resulting mixture was warmed to $20^{\circ} \mathrm{C}$ and was stirred at this temperature for $24 \mathrm{~h}$. The triethylammonium salt was filtered off and washed with tetrahydrofuran $(2 \mathrm{x}$ $10 \mathrm{~mL})$. The solvent was removed under reduced pressure before addition of DCM $(15 \mathrm{~mL})$ and $n$ pentane $(15 \mathrm{~mL})$ on the residue. The resulting solution was kept undisturbed at room temperature for 
$24 \mathrm{~h}$. The yellow crystalline product was isolated by filtration, washed with diethyl ether $(15 \mathrm{~mL})$, and dried in vacuo to afford 2-chloro-4,6-dimethyl-2-phenylbenzo[d][1,3,6,2]dioxazasilonine (3) (1.49 g, $22 \%)$. The spectroscopic data are in agreement with those reported in the literature ${ }^{1}$.

${ }^{1} \mathbf{H}$ NMR $\left(400 \mathrm{MHz}, \mathrm{CD}_{2} \mathrm{Cl}_{2}\right): \delta$ 7.43-7.38 (dd, $\mathrm{J}=8.0 \mathrm{~Hz}$ and $\left.1.2 \mathrm{~Hz}, 1 \mathrm{H}\right), 7.37-7.32(\mathrm{~m}, 2 \mathrm{H}), 7.31-$ $7.24(\mathrm{~m}, 2 \mathrm{H}), 7.24-7.15$ (m, 3H), 7.01-6.93 (m,1H), 5.73-5.71 (d, J = 0.4 Hz, 1H), 2.44 (s, 3H), 2.26 (s, 3H) ppm.

${ }^{13}$ CNMR (100 MHz, $\mathrm{CD}_{2} \mathrm{Cl}_{2}$ ): $\delta 172.1$ (1C), 169.3 (1C), 151.6 (1C), 138.3 (1C), 132.6 (1C), 132.5 (2 C), 129.8 (1C), 129.2 (1C), 127.9 (2 C), 121.1 (1C), 120.7 (1C), 115.8 (1C), 107.0 (1C), 24.8 (1C), 24.3 (1C) ppm.

\section{Chlorophenylbis[N,S-pyridine-2-thiolato(-)] $\operatorname{silicon(IV)~(5a)~}$}

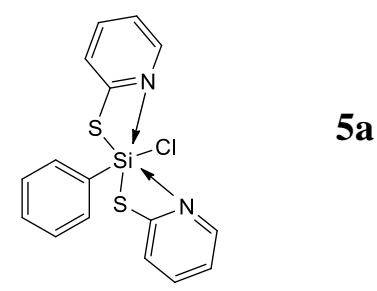

To a Schlenk tube with a stirred solution of 2-pyridinethiol $(14.2 \mathrm{mmol}, 1.59 \mathrm{~g})$ in tetrahydrofuran (30 $\mathrm{mL}$ ) was added triethylamine (14.2 mmol, $1.44 \mathrm{~g})$ and trichlorophenylsilane $(7.09 \mathrm{mmol}, 1.50 \mathrm{~g})$. The reaction mixture was then stirred at room temperature for $16 \mathrm{~h}$. The resulting triethylammonium salt was filtered off, washed with tetrahydrofuran $(2 \times 5 \mathrm{~mL})$ and discarded. The solvent was concentrated in vacuo, then acetonitrile $(20 \mathrm{~mL})$ was added. The resulting suspension was heated until a clear solution was obtained, which was then cooled slowly to $20^{\circ} \mathrm{C}$ then put in a freezer and kept undisturbed for 6 days. The resulting yellow crystalline solid was isolated by filtration and washed with diethyl ether $(2 \times 10 \mathrm{~mL})$ before being dried in vacuo to afford chlorophenylbis[N,S-pyridine-2 thiolato(-)]silicon(IV) (5a) (1.87 g, 73\%). The spectroscopic data are in agreement with those reported in the literature ${ }^{2}$.

${ }^{1} \mathbf{H}$ NMR $\left(400 \mathrm{MHz}, \mathrm{CD}_{2} \mathrm{Cl}_{2}\right): \delta 8.26-8.08$ (brs, $\left.2 \mathrm{H}\right), 7.77-7.70(\mathrm{~m}, 2 \mathrm{H})$, 7.66-7.60 (m, 2H), 7.48-7.43 (m, 2H), 7.24-7.18 (m, 3H), 7.12-7.05 (m, 2H) ppm.

${ }^{13}$ CNMR (100 MHz, $\mathrm{CD}_{2} \mathrm{Cl}_{2}$ ): $\delta 166.6$ (2C), 152.7 (1C), 141,3 (2C), 140.9 (2C), 132.7 (2C), 127.9 (1C), $127.4(2 \mathrm{C}), 125.6(2 \mathrm{C}), 118.2(2 \mathrm{C}) \mathrm{ppm}$.

\footnotetext{
${ }^{1}$ B. Theis, S. Metz, F. Back, C. Burschka, R. Tacke, Z. Anorg. Allg. Chem. 2009, 635, 1306-1312

2 J. A. Baus, C. Burschka, R. Bertemann, C. F. Guerra, F. M. Bickelhaupt, R. Tacke, Inorg. Chem. 2013, 52, 10664-10676
} 


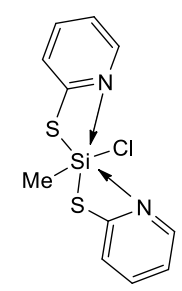

To a Schlenk tube with a solution of 2-pyridinethiol $(13.7 \mathrm{mmol}, 1.547 \mathrm{~g})$ in tetrahydrofuran (27.8 $\mathrm{mL}$ ) was added triethylamine $(13.7 \mathrm{mmol}, 1.81 \mathrm{~mL})$ and methyltrichlorosilane $(6.96 \mathrm{mmol}, 0.817 \mathrm{~mL})$. The reaction mixture was then stirred at room temperature for $16 \mathrm{~h}$. The resulting precipitate was filtered off, washed with tetrahydrofuran $(2 \times 5 \mathrm{~mL})$ and discarded. The solvent was concentrated in vacuo, followed by the addition of acetonitrile $(15 \mathrm{~mL})$. The resulting suspension was heated until a clear solution was obtained, which was then cooled slowly to $20^{\circ} \mathrm{C}$ then put in a freezer and kept undisturbed for 6 days. The resulting colorless crystalline solid was isolated by filtration and washed with diethyl ether $(2 \times 10 \mathrm{~mL})$ before being dried in vacuo to afford chloromethylbis[N,S-pyridine-2 thiolato(-)]silicon(IV) (5b) (180 mg, 9\%). The spectroscopic data are in agreement with those reported in the literature ${ }^{2}$.

${ }^{1} \mathbf{H}$ NMR $\left(400 \mathrm{MHz}, \mathrm{CD}_{2} \mathrm{Cl}_{2}\right): \delta$ 8.10-7.99 (m, 2H), 7.77-7.67 (m, 2H), 7.50-7.42 (m, 2H), 7.11-6.98 (m, 2H), $1.16(\mathrm{~s}, 3 \mathrm{H}) \mathrm{ppm}$.

${ }^{13}$ CNMR (100 MHz, $\mathrm{CD}_{2} \mathrm{Cl}_{2}$ ): $\delta 168.2$ (2C), 141.0 (2C), 140.4 (2C), 125.4 (2C), 117.9 (2C), 26.0

(1C) $\mathrm{ppm}$.

\section{Phenylbis[N,S-pyridine-2-thiolato(-)]silicon(IV) Iodide (5d)}

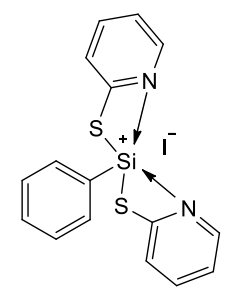

5d

Iodotrimethylsilane $(6.95 \mathrm{mmol}, 1.39 \mathrm{~g})$ was added in a single portion to a stirred solution of chlorophenylbis[N,S-pyridine-2 thiolato(-)]silicon(IV) (6a) $(2.77 \mathrm{mmol}, 1.00 \mathrm{~g})$ in acetonitrile (30 $\mathrm{mL}$ ). The resulting reaction mixture was then stirred at $65^{\circ} \mathrm{C}$ for 3 hours and at room temperature for 3 days. After that, the reaction mixture was concentrated in vacuo, then disolved in acetonitrile $(30 \mathrm{~mL})$. The resulting suspension was heated until a clear solution was obtained, which was then cooled slowly to $20^{\circ} \mathrm{C}$ then put in a freezer and kept undisturbed at this temperature for 3 days. The resulting 
colorless crystalline solid was isolated by filtration, washed with diethyl ether $(2 \times 5 \mathrm{~mL})$, and dried in to afford phenylbis[N,S-pyridine-2-thiolato(-)]silicon(IV) Iodide (5d) (300 $\mathrm{mg}, 24 \%$ ). The spectroscopic data are in agreement with those reported in the literature. ${ }^{1}$

${ }^{1} \mathbf{H}$ NMR $\left(400 \mathrm{MHz}, \mathrm{CD}_{2} \mathrm{Cl}_{2}\right): \delta 8.46-8.22(\mathrm{~m}, 2 \mathrm{H}), 8.06-7.82(\mathrm{~m}, 2 \mathrm{H}), 7.73-7.57(\mathrm{~m}, 4 \mathrm{H})$, 7.43-7.24 $(\mathrm{m}, 5 \mathrm{H}) \mathrm{ppm}$.

\section{Phenyltris(phenylthio)silane (7)}

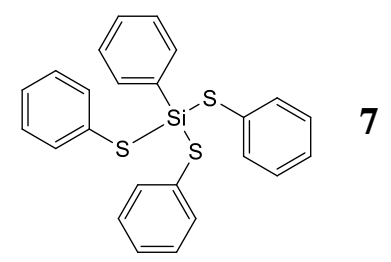

To a Schlenk flask was added the phenyl silane ( $4 \mathrm{mmol}, 0.49 \mathrm{~mL})$, the thiopyridine ( $12 \mathrm{mmol}, 1.32$ g) and $\mathrm{RhCl}\left(\mathrm{PPh}_{3}\right)_{3}(0.128 \mathrm{mmol}, 120 \mathrm{mg})$ in $10 \mathrm{~mL}$ of hexane. The reaction mixture was stirred for 15 hours then filtrated, concentrated under vacuo and pentane was added. An oil appeared and this was taken out to give pure product phenyltris(phenylthio)silane (7) (600 mg, 35\%). The spectroscopic data are in agreement with those reported in the literature ${ }^{3}$.

${ }^{1} \mathbf{H}$ NMR (400 MHz, $\left.\mathrm{CDCl}_{3}\right): \delta$ 7.65-7.09 (m, 20H) ppm.

${ }^{13}$ C NMR (100 MHz, CDCl $)$ ): $\delta 135.1$ (6C), 134.9 (3C), 132.0 (1C), 131.1 (1C), 128.9 (6C), 128.8 (2C), $128.0(2 \mathrm{C}), 127.6(3 \mathrm{C}) \mathrm{ppm}$.

\section{Photocatalytic reaction}

\section{Standard procedure}

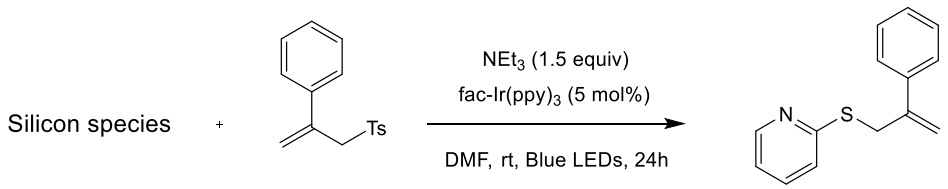

To a Schlenk flask was added the silicon complex 5a-d, $\operatorname{Ir}(\mathrm{ppy})(5 \mathrm{~mol} \%)$, and allyl sulfone 2 . The degassed solvent $(0.1 \mathrm{~mol} / \mathrm{L}$ or $0.067 \mathrm{~mol} / \mathrm{L})$ was then introduced followed by the amine $(1.5 \mathrm{eq}$.$) and$

${ }^{3}$ J. B. Baruah, K. Osakada, T. Yamamoto, Organometallics. 1996, 15, 456-459 
the reaction mixture was irradiated with blue LEDs $(470 \mathrm{~nm})$ at room temperature for $24 \mathrm{~h}$ under an argon atmosphere. The reaction mixture was diluted with diethyl ether, washed with water (2 times), dried over $\mathrm{MgSO} 4$ and evaporated under reduced pressure. The crude residue was purified by flash chromatography.

\section{Photocatalytic reaction using Chlorobenzylbis[N,S-pyridine-2-thiolato(-)]silicon(IV) complex}

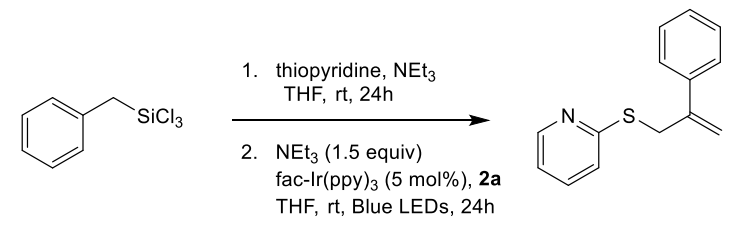

To a dry Schlenk flask was added the benzyl trichlorosilane $(2.0 \mathrm{mmol}, 0.35 \mathrm{~mL})$, triethylamine $(4.0$ mmol, $0.56 \mathrm{~mL})$ and thiopyridine $(4.0 \mathrm{mmol}, 445 \mathrm{mg})$. The Schlenk flask was sealed with a rubber septum and evacuated / purged with vacuum / argon three times. Then $14 \mathrm{~mL}$ of dry and degazed THF were added and the solution was stirred for one day. The triethylammonium salt was filtrated off by canula then $7 \mathrm{~mL}$ of this solution were added to a dry Schlenk flask containing Irppy $(0.0255 \mathrm{mmol}$, $14.73 \mathrm{mg}$ ) triethylamine ( $1 \mathrm{mmol}, 0.14 \mathrm{~mL}$ ) and allyl sulfone 2 ( $0.45 \mathrm{mmol}, 122 \mathrm{mg})$. The reaction mixture was irradiated with blue LEDs $(470 \mathrm{~nm})$ at room temperature for $24 \mathrm{~h}$ under an argon atmosphere. The reaction mixture was diluted with diethyl ether, washed with water ( 2 times), dried over $\mathrm{MgSO}_{4}$ and evaporated under reduced pressure and analyzed by NMR using TMOP (1 equiv) as an internal standard.

\section{Photocatalytic reaction using aldrithiol ${ }^{\mathrm{TM}}$}

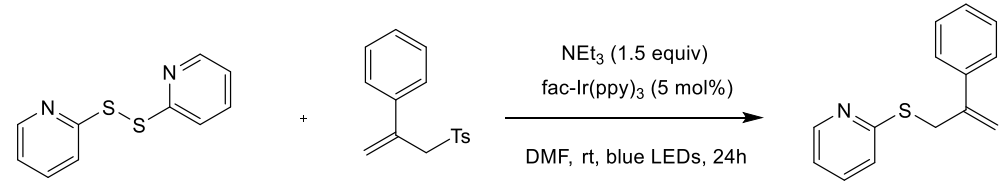

To a dry Schlenk flask was added aldrithiol ${ }^{\mathrm{TM}}(0.3 \mathrm{mmol}, 66 \mathrm{mg})$, the $\operatorname{Ir}(\mathrm{ppy})(0.005 \mathrm{~mol}, 3.2 \mathrm{mg})$ and the allyl sulfone $2(0.1 \mathrm{mmol}, 27.2 \mathrm{mg})$. The Schlenk flask was sealed with a rubber septum and evacuated / purged with vacuum / argon three times. Then $1.5 \mathrm{~mL}$ of dry and degazed DMF was introduced followed by addition of the triethylamine $(0.15 \mathrm{mmol}, 0.021 \mathrm{~mL})$ and the reaction mixture was irradiated with blue LEDs $(470 \mathrm{~nm})$ at room temperature for $24 \mathrm{~h}$ under an argon atmosphere. The reaction mixture was diluted with diethyl ether, washed with water (2 times), dried over $\mathrm{MgSO}_{4}$ and 
evaporated under reduced pressure. The crude residue was analyzed by NMR using TMOP (1 equiv) as an internal standard.

\section{Characterisation of the thiopyridine product}

2-((2-phenylallyl)thio)pyridine (3b)

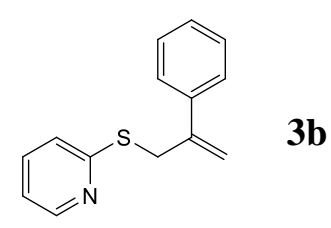

To a dried Schlenk flask was added the silicon complex (3 equiv), the acceptor (1 equiv), the Irppy (5 mol\%), and the $\mathrm{NEt}_{3}$ (1.5 equiv) in dried and degassed DMF $(0.66 \mathrm{M})$. The reaction mixture was irradiated with blue LEDs $(477 \mathrm{~nm})$ for $24 \mathrm{~h}$ then diluted with diethyl ether washed with water (2 times) dried over $\mathrm{MgSO}_{4}$, filtered, evaporated under reduced pressure and analyzed by ${ }^{1} \mathrm{H}$ NMR $\mathrm{CDCl}_{3}$.

${ }^{1} \mathbf{H}$ NMR $\left(400 \mathrm{MHz}, \mathrm{CDCl}_{3}\right): \delta 8.53-8.41(\mathrm{~d}, \mathrm{~J}=4.8 \mathrm{~Hz}, 1 \mathrm{H}), 7.54-7.42(\mathrm{~m}, 3 \mathrm{H}), 7.38-7.27(\mathrm{~m}, 3 \mathrm{H})$, 7.16-7.01 (m, 1H), 7.02-6.95 (m, 1H), 5.50-5.45 (s, 1H), 5.45-5.41 (s, 1H), 4.38-4.32 (s, 2H) ppm.

${ }^{13}$ CNMR (100 MHz, $\left.\mathrm{CDCl}_{3}\right)$ : $\delta 158.9$ (1C), 149.6 (1C), 143.7 (1C), 139.7 (1C), 136.0 (1C), 128.5 (2C), 128.0 (1C), 126.4 (2C), 122.6 (1C), 119.7 (1C), 115.7 (1C), 34.7 (1C) ppm.

HRMS calc. for $\left[\mathrm{C}_{14} \mathrm{H}_{14} \mathrm{NS}\right]$; 228.0841 found 228.0841 .

IR (neat): $3051,928,1577,1557,1495,1454,1413,1281,1122 \mathrm{~cm}^{-1}$. 


\section{Electrochemical measurement}

The voltammetric measurement was recorded with a three electrodes apparatus in degassed THF with $\mathrm{Bu}_{4} \mathrm{NPF}_{6}(100 \mathrm{mM})$ as support electrolyte at $22^{\circ} \mathrm{C}$. Measurements were monitored on an AutoLab PSTAT10 electrochemical workstation. Cyclic voltammetry (CV) was used to estimate the redox potential (half-wave potential). The CVs were obtained with a step potential of $0.009 \mathrm{~V}$ at a scan rate of $0.1 \mathrm{~V} . \mathrm{s}^{-1}\left(0.05 \mathrm{~V} . \mathrm{s}^{-1}\right.$ for 7$)$. Glassy carbon, platinum plate, and saturated calomel were used as working, counter, and reference electrodes, respectively.

\section{Voltammetry of phenyltrichlorosilane}

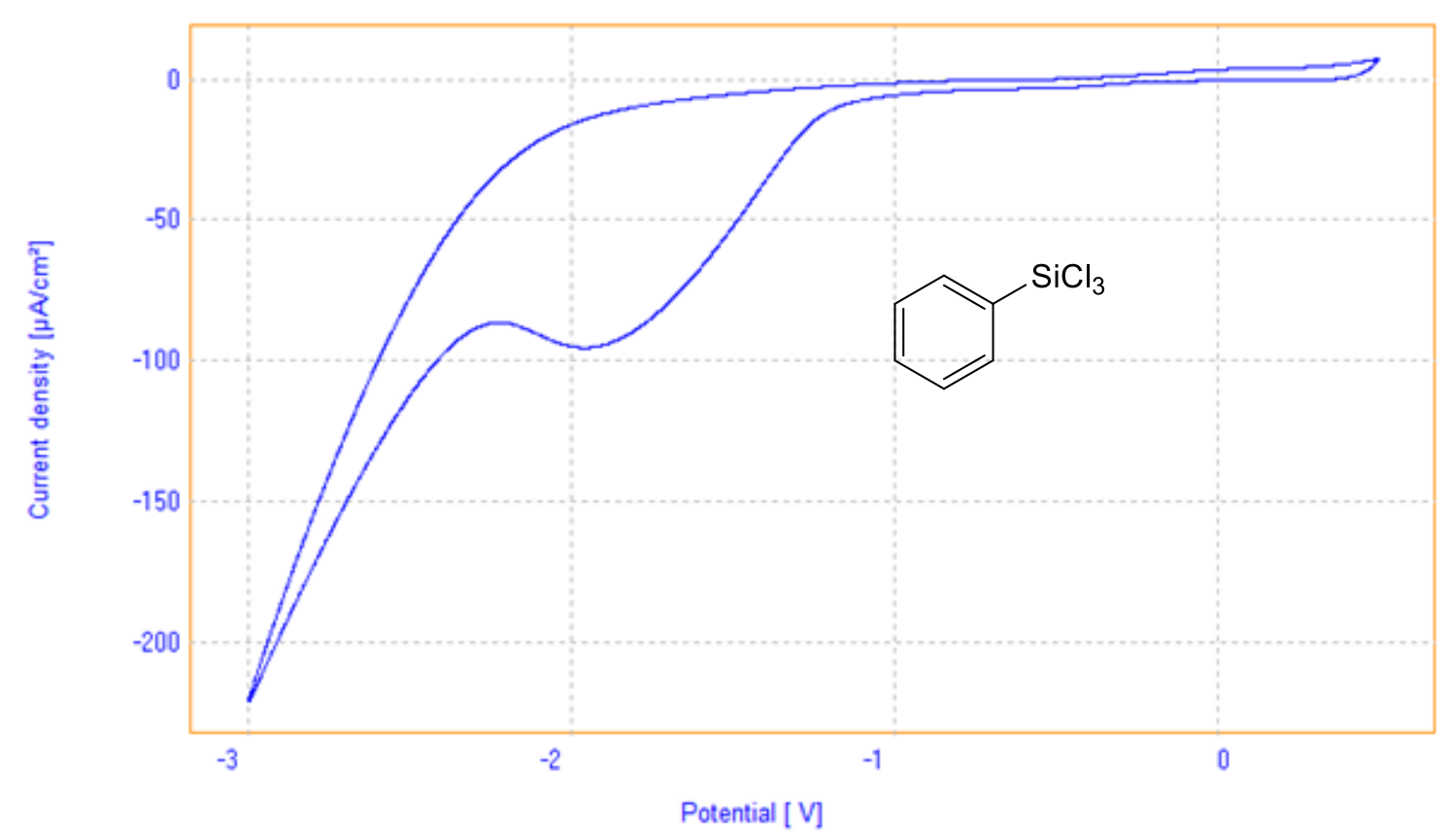


Voltammetry of 2-chloro-4,6-dimethyl-2-phenylbenzo[d][1,3,6,2]dioxazasilonine

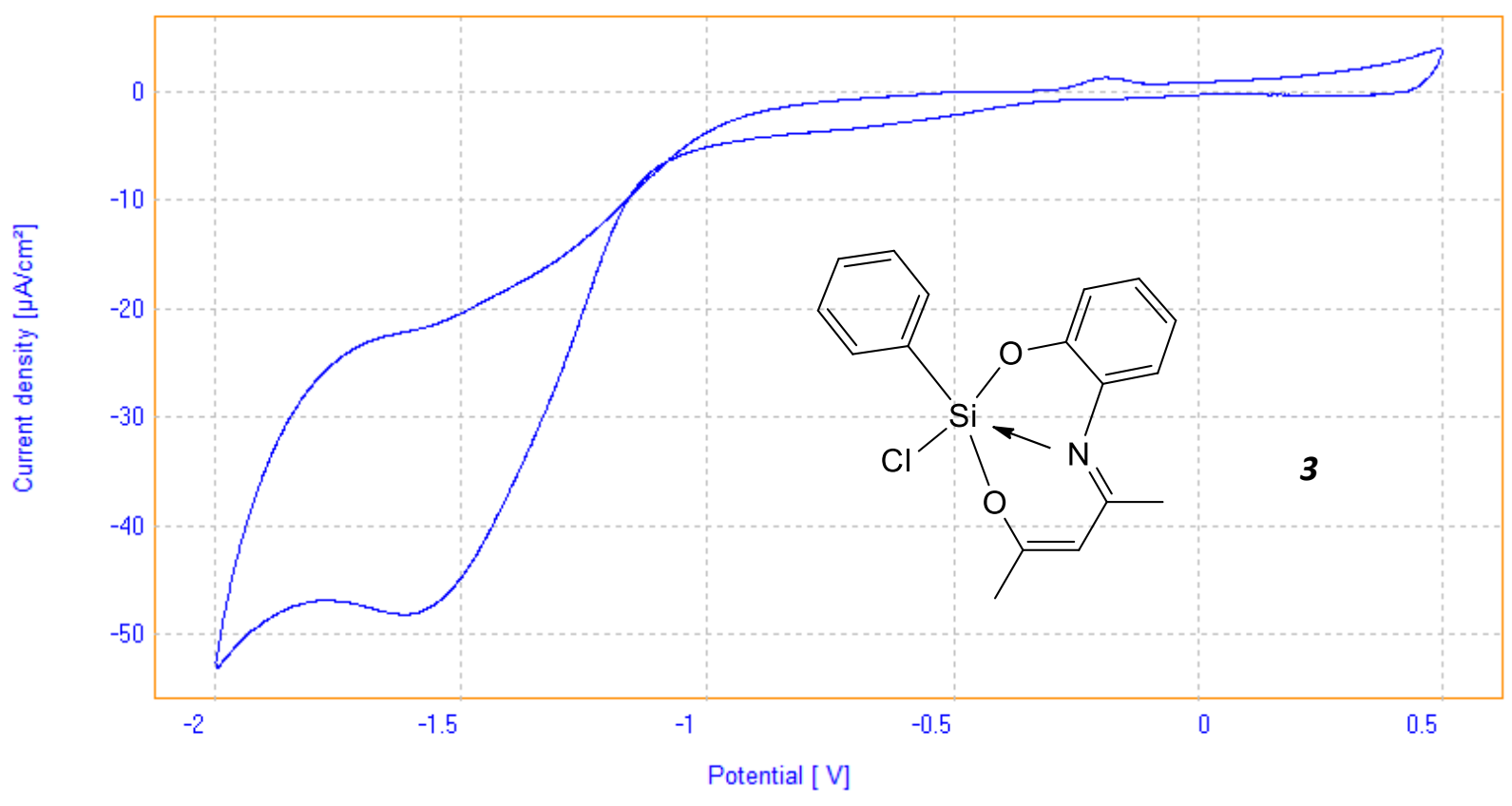

Voltammetry of Chlorophenylbis[N,S-pyridine-2-thiolato(-)]silicon(IV)

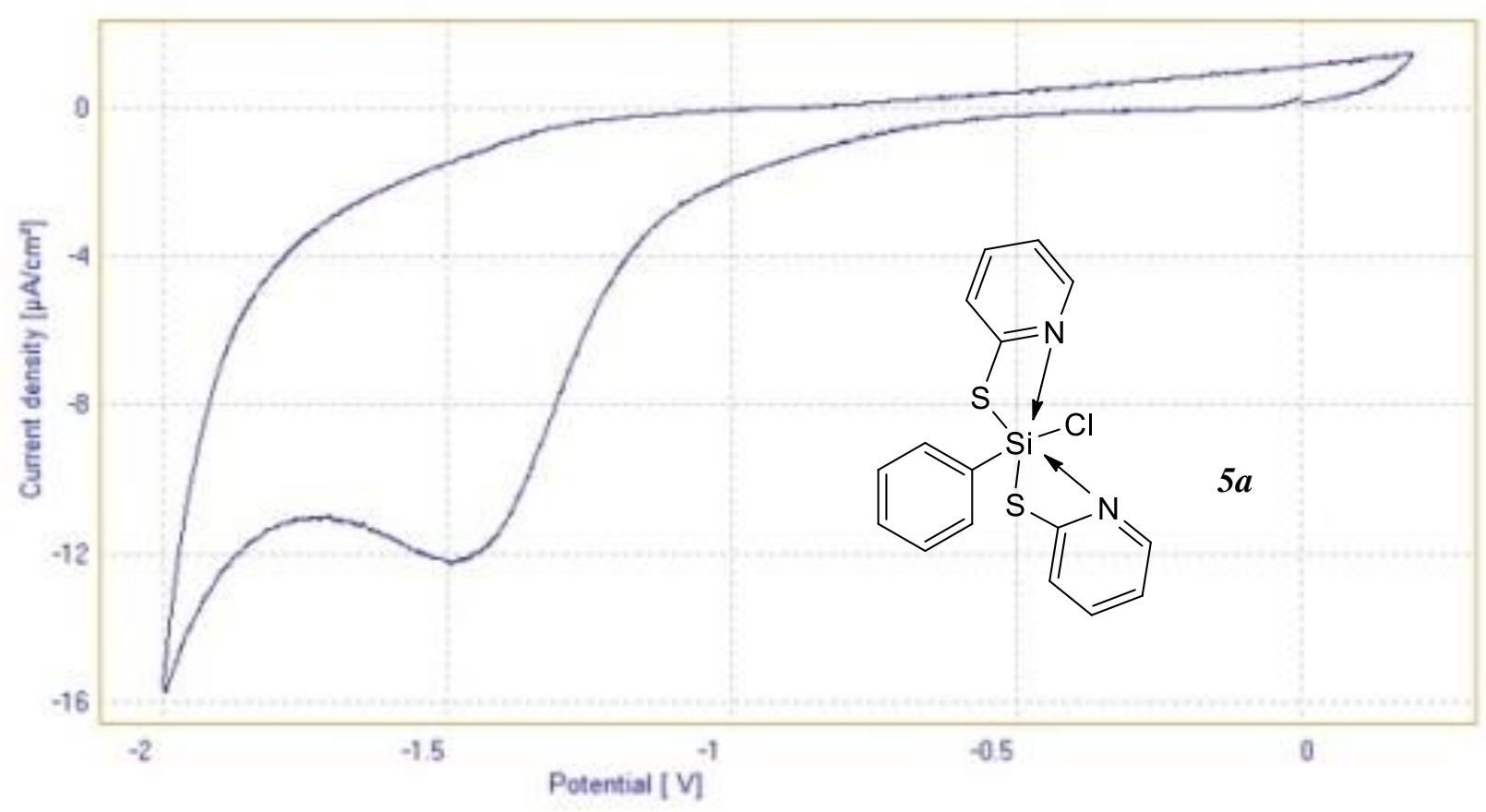


Voltammetry of 2,2'-((chloro(methyl)silanediyl)bis(sulfanediyl))dipyridine

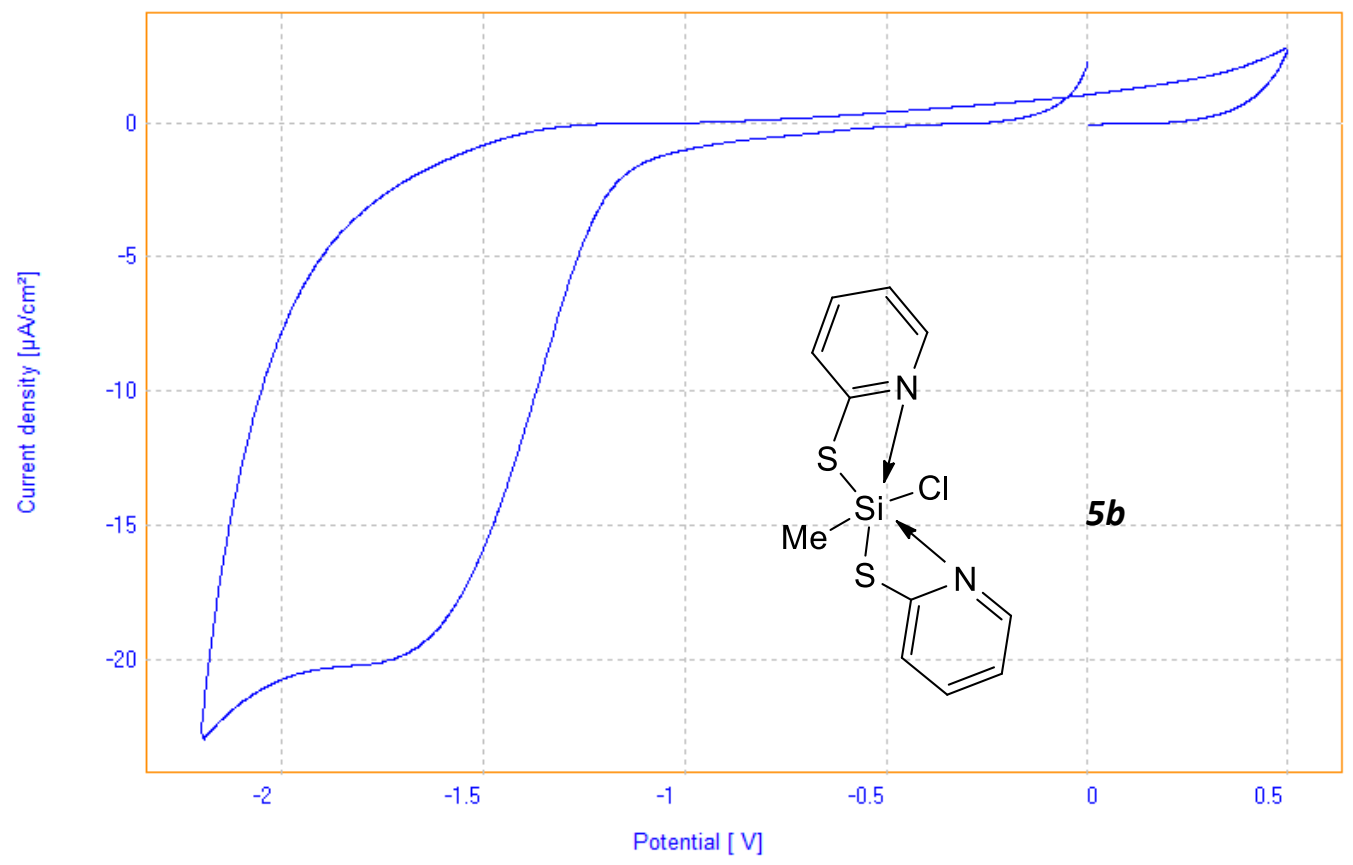

Voltammetry of phenyltris(phenylthio)silane

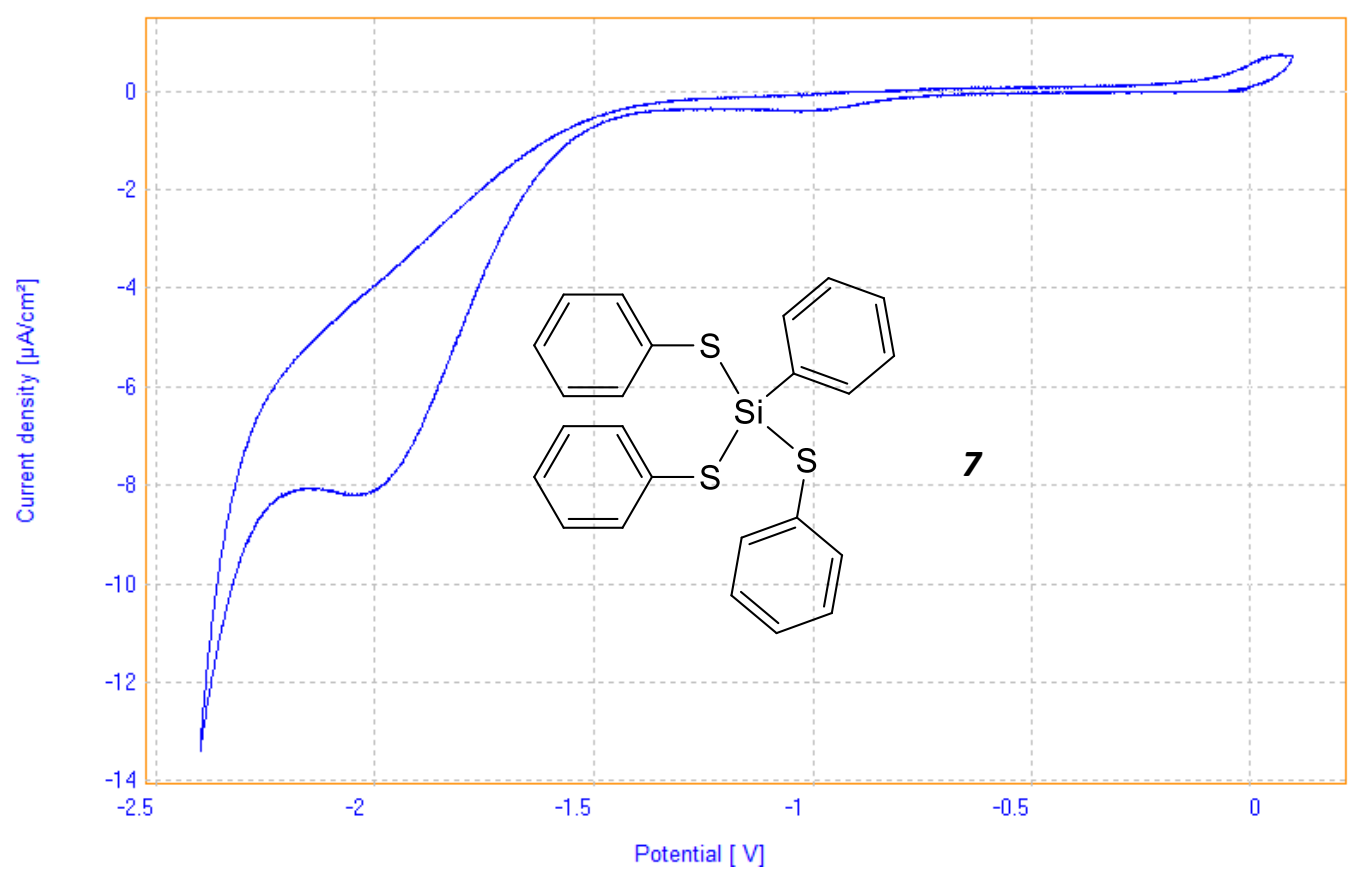




\section{$V$. Coordinates of calculated species}

\section{Product 5a}

$$
35
$$

Energy $=-2271.578758134$

$\begin{array}{lrrr}\mathrm{Si} & 0.1339412 & 0.2623132 & -0.1200367 \\ \mathrm{~S} & -0.8499136 & 2.2294657 & 0.8308704 \\ \mathrm{~S} & 1.1129507 & -1.7017118 & -1.0832169 \\ \mathrm{~N} & 1.5482311 & 1.5428528 & 0.2086740 \\ \mathrm{~N} & -1.2597695 & -1.0644854 & -0.3264308 \\ \mathrm{C} & 2.8844381 & 1.5704412 & 0.0838227 \\ \mathrm{C} & 3.6040984 & 2.7021672 & 0.4322368 \\ \mathrm{C} & 2.8968594 & 3.8196105 & 0.9245919 \\ \mathrm{C} & 1.5165523 & 3.7752736 & 1.0669684 \\ \mathrm{C} & 0.8366116 & 2.5918252 & 0.7086980 \\ \mathrm{C} & -0.5635782 & -2.0848213 & -0.9014932 \\ \mathrm{C} & -1.2429127 & -3.2732481 & -1.2437341 \\ \mathrm{C} & -2.5967870 & -3.3735682 & -0.9534178 \\ \mathrm{C} & -3.2780342 & -2.3077491 & -0.3280679 \\ \mathrm{C} & -2.5645360 & -1.1589665 & -0.0261096 \\ \mathrm{H} & 3.3550542 & 0.6588802 & -0.2954389 \\ \mathrm{H} & 4.6911659 & 2.7174820 & 0.3275170 \\ \mathrm{H} & 3.4416002 & 4.7272870 & 1.2044682 \\ \mathrm{H} & 0.9496361 & 4.6230131 & 1.4577966 \\ \mathrm{H} & -0.6920925 & -4.0899536 & -1.7152634 \\ \mathrm{H} & -3.1381678 & -4.2917157 & -1.2041045 \\ \mathrm{H} & -4.3396092 & -2.3777261 & -0.0808068 \\ \mathrm{H} & -3.0127189 & -0.2918390 & 0.4674307 \\ \mathrm{C} & -0.1825354 & 0.9721625 & -1.9067204 \\ \mathrm{C} & -1.4781956 & 1.2863731 & -2.3518113 \\ \mathrm{C} & -1.7124543 & 1.7913603 & -3.6353689 \\ \mathrm{C} & -0.6411425 & 2.0089779 & -4.5080920 \\ \mathrm{C} & 0.6585207 & 1.7095786 & -4.0857659 \\ \mathrm{C} & 0.8764063 & 1.1919520 & -2.8045325 \\ \mathrm{H} & -2.3341756 & 1.1505124 & -1.6809725 \\ \mathrm{H} & -2.7353494 & 2.0231923 & -3.9515349 \\ \mathrm{H} & -0.8177957 & 2.4093783 & -5.5120502 \\ \mathrm{H} & 1.5069779 & 1.8717142 & -4.7595500 \\ \mathrm{H} & 1.9024301 & 0.9425993 & -2.5110427 \\ \mathrm{C} 1 & 0.4931078 & -0.5431913 & 1.9063140 \\ & & & \end{array}$

\section{Product 5a reduced}

\section{5}

Energy $=-2271.595248298$

$\begin{array}{lr}\text { Si } & 0.1353387 \\ \text { S } & -0.8802060 \\ \text { S } & 1.1481203 \\ \mathrm{~N} & 1.5077421 \\ \mathrm{~N} & -1.2162186 \\ \mathrm{C} & 2.8652255 \\ \mathrm{C} & 3.5817543 \\ \mathrm{C} & 2.9013113 \\ \mathrm{C} & 1.4965730 \\ \mathrm{C} & 0.8191199 \\ \mathrm{C} & -0.5411045\end{array}$

0.2588526

2.2027725

$-1.6829581$

1.5072028

$-1.0376558$

1.5322734

2.6713658

3.8084213

3.7549483

2.5865035

$-2.0871739$
-0.1053846
0.8435756
-1.0660396
0.2179211
-0.3102547
0.0854481
0.4123931
0.9008308
1.0649792
0.7268977
-0.8928430 


$\begin{array}{lr}\mathrm{C} & -1.2209719 \\ \mathrm{C} & -2.6046178 \\ \mathrm{C} & -3.2584581 \\ \mathrm{C} & -2.5421522 \\ \mathrm{H} & 3.3306963 \\ \mathrm{H} & 4.6701640 \\ \mathrm{H} & 3.4530448 \\ \mathrm{H} & 0.9331847 \\ \mathrm{H} & -0.6707924 \\ \mathrm{H} & -3.1573991 \\ \mathrm{H} & -4.3228494 \\ \mathrm{H} & -2.9773847 \\ \mathrm{C} & -0.1837889 \\ \mathrm{C} & -1.4815388 \\ \mathrm{C} & -1.7165016 \\ \mathrm{C} & -0.6444736 \\ \mathrm{C} & 0.6575438 \\ \mathrm{C} & 0.8748439 \\ \mathrm{H} & -2.3394174 \\ \mathrm{H} & -2.7441704 \\ \mathrm{H} & -0.8213400 \\ \mathrm{H} & 1.5111670 \\ \mathrm{H} & 1.9036844 \\ \mathrm{C} 1 & 0.5026853\end{array}$

$$
\begin{array}{r}
-3.2517867 \\
-3.3495322 \\
-2.2705490 \\
-1.1299392 \\
0.6087616 \\
2.6736406 \\
4.7175330 \\
4.6036972 \\
-4.0720575 \\
-4.2569758 \\
-2.3253452 \\
-0.2712100 \\
0.9755757 \\
1.2584020 \\
1.7621559 \\
2.0125562 \\
1.7454221 \\
1.2311489 \\
1.0908422 \\
1.9652519 \\
2.4113516 \\
1.9341991 \\
1.0138289 \\
-0.5720874
\end{array}
$$

\section{$(\mathrm{PhS})_{2} \mathrm{Si}(\mathrm{Cl}) \mathrm{Ph}$}

\section{7}

Energy $=-2239.540640183$

$\begin{array}{lr}\text { Si } & -0.0767772 \\ \text { Cl } & 0.1026238 \\ \text { S } & 1.6416238 \\ \text { S } & -2.0061521 \\ \mathrm{C} & -0.0569185 \\ \mathrm{C} & 0.1553759 \\ \mathrm{C} & 0.1845830 \\ \mathrm{C} & 0.0044678 \\ \mathrm{C} & -0.2075522 \\ \mathrm{C} & -0.2395849 \\ \mathrm{C} & -1.9415713 \\ \mathrm{C} & -1.7318463 \\ \mathrm{C} & -1.7633368 \\ \mathrm{C} & -2.0306988 \\ \mathrm{C} & -2.2531625 \\ \mathrm{C} & -2.2006666 \\ \mathrm{C} & 1.6588731 \\ \mathrm{C} & 2.1456606 \\ \mathrm{C} & 2.2115526 \\ \mathrm{C} & 1.8113847 \\ \mathrm{C} & 1.3370521 \\ \mathrm{C} & 1.2569767 \\ \mathrm{H} & 0.2973312 \\ \mathrm{H} & 0.3488922 \\ \mathrm{H} & 0.0285417 \\ \mathrm{H} & -0.3506275 \\ \mathrm{H} & -0.4127245 \\ \mathrm{H} & -1.5363951 \\ \mathrm{H} & -1.5794847 \\ \mathrm{H} & -2.0607266 \\ \mathrm{H} & -2.4614683 \\ & \end{array}$

$-0.7818033$

1.2063706

$-1.9035641$

$-1.5744784$

$-0.8434755$

0.3042452

0.2155560

$-1.0214801$

$-2.1716256$

$-2.0835776$

$-1.8019299$

$-0.7274621$

$-0.9435647$

$-2.2175838$

$-3.2843928$

$-3.0824325$

$-1.6506148$

$-0.4510439$

$-0.2914547$

$-1.3290010$

$-2.5279072$

$-2.6912534$

1. 2762500

1.1169733

$-1.0903272$

$-3.1409999$

$-2.9901267$

0.2715158

$-0.1053151$

$-2.3789357$

$-4.2851731$
$-1.2400706$

$-0.9621321$

$-0.3279859$

$-0.0061425$

$-0.2687835$

0.2957367

1. 1605156

1. 4612980

$-1.7081489$

$-1.2251113$

$-0.0785870$

0.5115846

$-1.9098701$

$-2.3759276$

$-3.6600614$

$-4.5251406$

$-4.0846953$

$-2.8017429$

$-1.7148409$

$-3.9859453$

$-5.5311657$

$-4.7475753$

$-2.4931567$

1. 9742514
0.7539276

0.0960718

0.0935898

0.2032258

2. 6217565

3. 4076918

4. 8030126

5.4312438

4. 6619601

3.2673369

$-1.5831537$

$-2.4616352$

$-3.8414572$

$-4.3541951$

$-3.4780788$

$-2.0951675$

$-1.6933658$

$-2.2339282$

$-3.6216669$

$-4.4704064$

$-3.9275194$

$-2.5423654$

2. 9257072

5. 4021806

6.5238079

5.1505268

2.6774259

$-2.0658800$

$-4.5204366$

$-5.4363518$

$-3.8703618$ 


$\begin{array}{rrrr}\mathrm{H} & -2.3607346 & -3.9176928 & -1.4072016 \\ \mathrm{H} & 2.4620666 & 0.3542572 & -1.5671732 \\ \mathrm{H} & 2.5849546 & 0.6491218 & -4.0396021 \\ \mathrm{H} & 1.8658024 & -1.2022508 & -5.5563636 \\ \mathrm{H} & 1.0108150 & -3.3390898 & -4.5851042 \\ \mathrm{H} & 0.8685508 & -3.6188951 & -2.1157027\end{array}$

\section{$(\mathrm{PhS})_{2} \mathrm{Si}(\mathrm{Cl}) \mathrm{Ph}$ reduced}

\begin{tabular}{lrrr}
37 & \multicolumn{3}{c}{} \\
Energy $=-2239.537510465$ & \\
Si & -0.1500934 & -1.1348488 & 0.9258758 \\
C1 & -0.2545349 & 0.9019428 & 0.1951824 \\
S & 1.8529191 & -1.8650776 & 0.3270731 \\
$\mathrm{~S}$ & -1.9114323 & -2.1405851 & -0.4439341 \\
$\mathrm{C}$ & 0.1426905 & -0.8939630 & 2.7889075 \\
$\mathrm{C}$ & -0.3981283 & 0.2095878 & 3.4999046 \\
$\mathrm{C}$ & -0.3848425 & 0.2577576 & 4.8954507 \\
$\mathrm{C}$ & 0.1752492 & -0.7885761 & 5.6431186 \\
$\mathrm{C}$ & 0.7195307 & -1.8911308 & 4.9611503 \\
$\mathrm{C}$ & 0.6934262 & -1.9469722 & 3.5685542 \\
$\mathrm{C}$ & -2.0141081 & -1.5186893 & -2.1046336 \\
$\mathrm{C}$ & -2.3609477 & -0.1754113 & -2.3787891 \\
$\mathrm{C}$ & -2.4281557 & 0.2934392 & -3.6921028 \\
$\mathrm{C}$ & -2.1661056 & -0.5612365 & -4.7734909 \\
$\mathrm{C}$ & -1.8211048 & -1.8948139 & -4.5134411 \\
$\mathrm{C}$ & -1.7359604 & -2.3647513 & -3.2021836 \\
$\mathrm{C}$ & 1.6978524 & -2.2254076 & -1.4194790 \\
$\mathrm{C}$ & 1.4938297 & -1.1965879 & -2.3573767 \\
$\mathrm{C}$ & 1.4773107 & -1.4817623 & -3.7236960 \\
$\mathrm{C}$ & 1.6799317 & -2.7900437 & -4.1796180 \\
$\mathrm{C}$ & 1.8748571 & -3.8185045 & -3.2515653 \\
$\mathrm{C}$ & 1.8764461 & -3.5413978 & -1.8802171 \\
$\mathrm{H}$ & -0.8220517 & 1.0486792 & 2.9378059 \\
$\mathrm{H}$ & -0.8052995 & 1.1316200 & 5.4094072 \\
$\mathrm{H}$ & 0.1884600 & -0.7481249 & 6.7381127 \\
$\mathrm{H}$ & 1.1731450 & -2.7144010 & 5.5273141 \\
$\mathrm{H}$ & 1.1166685 & -2.8236718 & 3.0633279 \\
$\mathrm{H}$ & -2.5584911 & 0.4968665 & -1.5402244 \\
$\mathrm{H}$ & -2.6939625 & 1.3419150 & -3.8756564 \\
$\mathrm{H}$ & -2.2228317 & -0.1904370 & -5.8031727 \\
$\mathrm{H}$ & -1.5940921 & -2.5750430 & -5.3433359 \\
$\mathrm{H}$ & -1.4323766 & -3.3973170 & -3.0059016 \\
$\mathrm{H}$ & 1.3267785 & -0.1763483 & -2.0032153 \\
$\mathrm{H}$ & 1.2834452 & -0.6752448 & -4.4378982 \\
$\mathrm{H}$ & 1.6608146 & -3.0090304 & -5.2528079 \\
$\mathrm{H}$ & 2.0158873 & -4.8499894 & -3.5951552 \\
$\mathrm{H}$ & 2.0119767 & -4.3456030 & -1.1509425
\end{tabular}


VI. ${ }^{1} \mathrm{H},{ }^{13} \mathrm{C}$ spectra

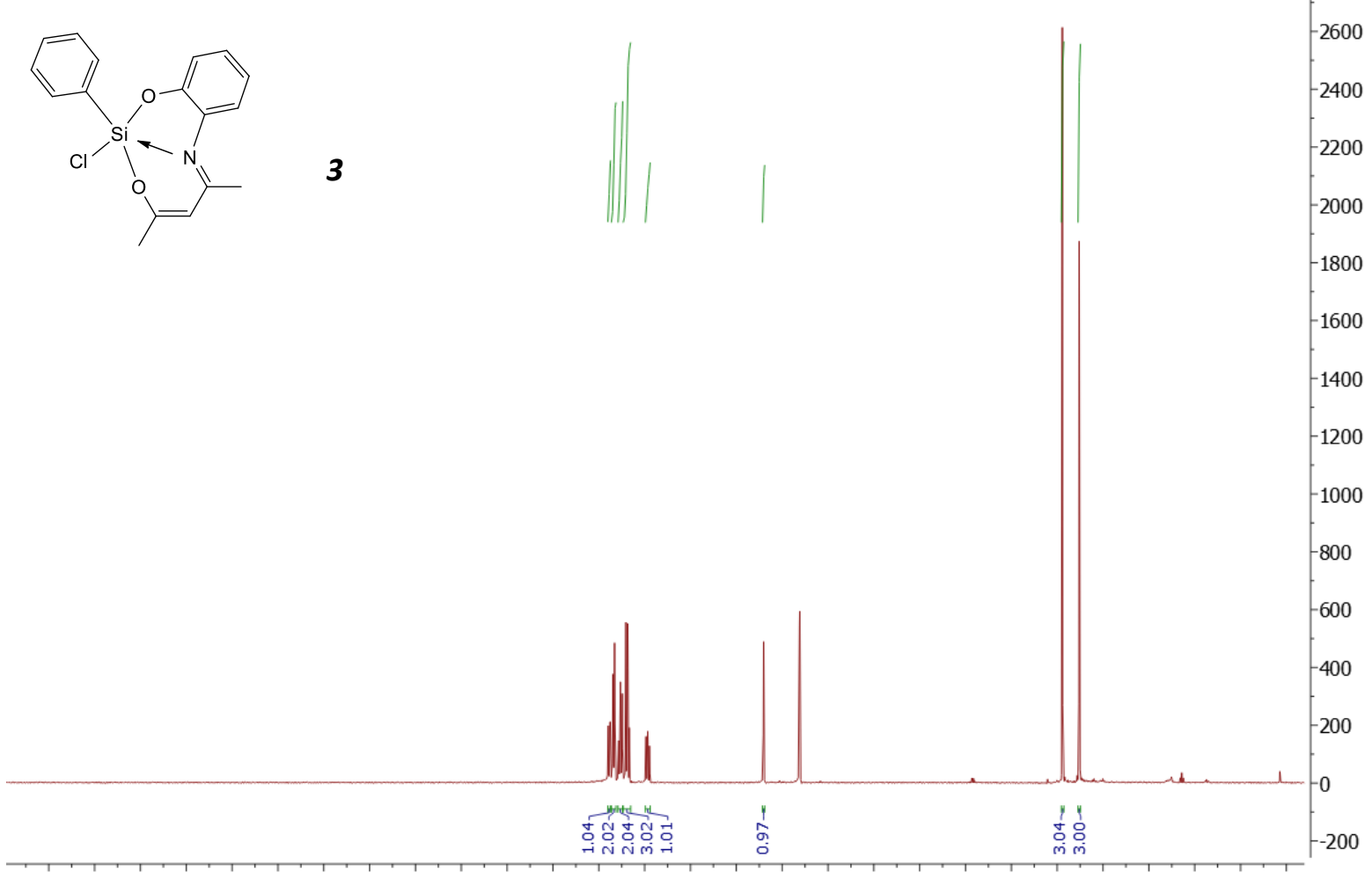

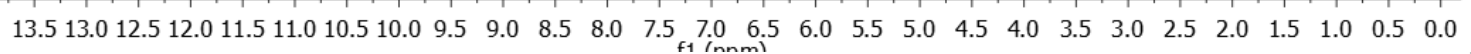

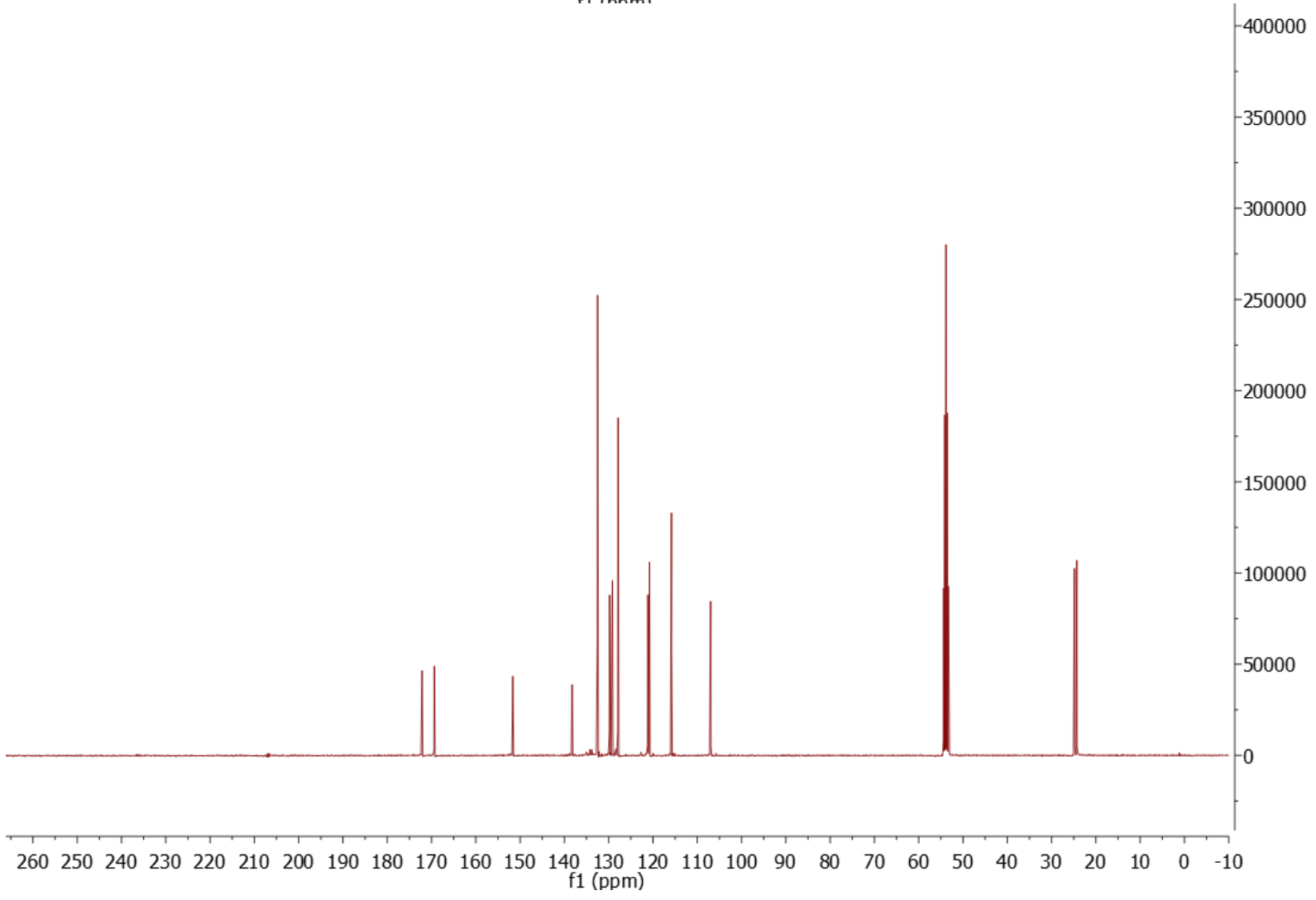




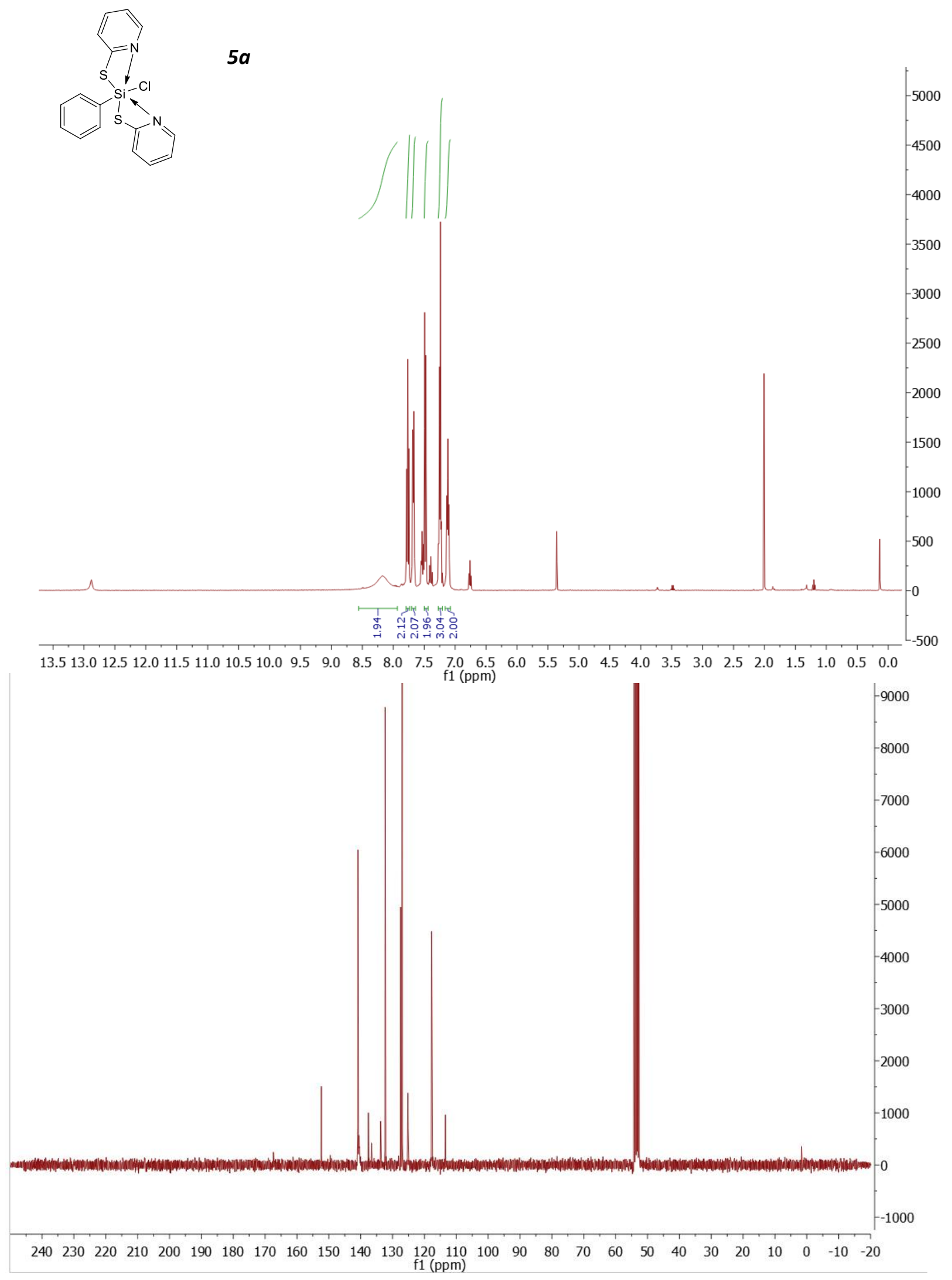




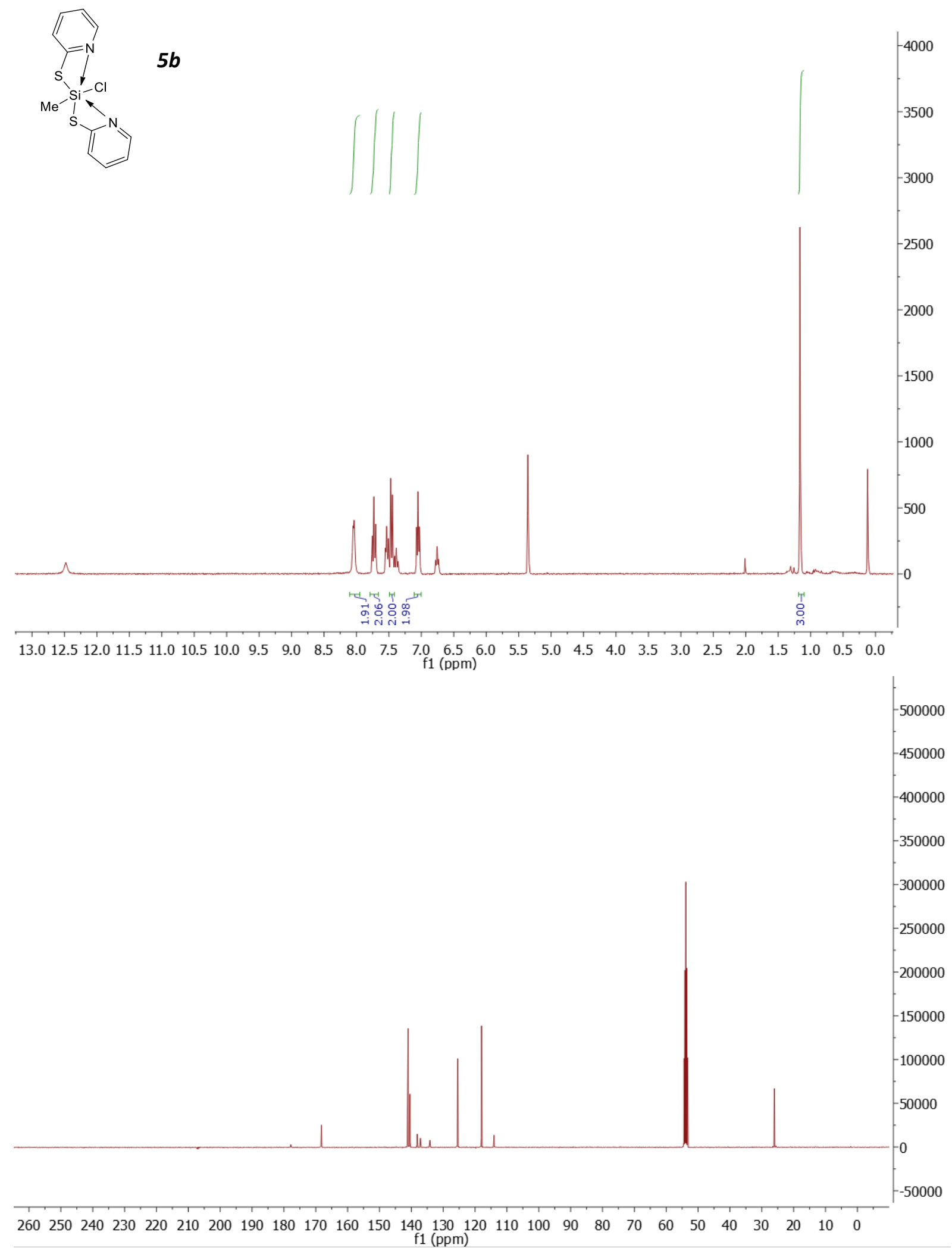




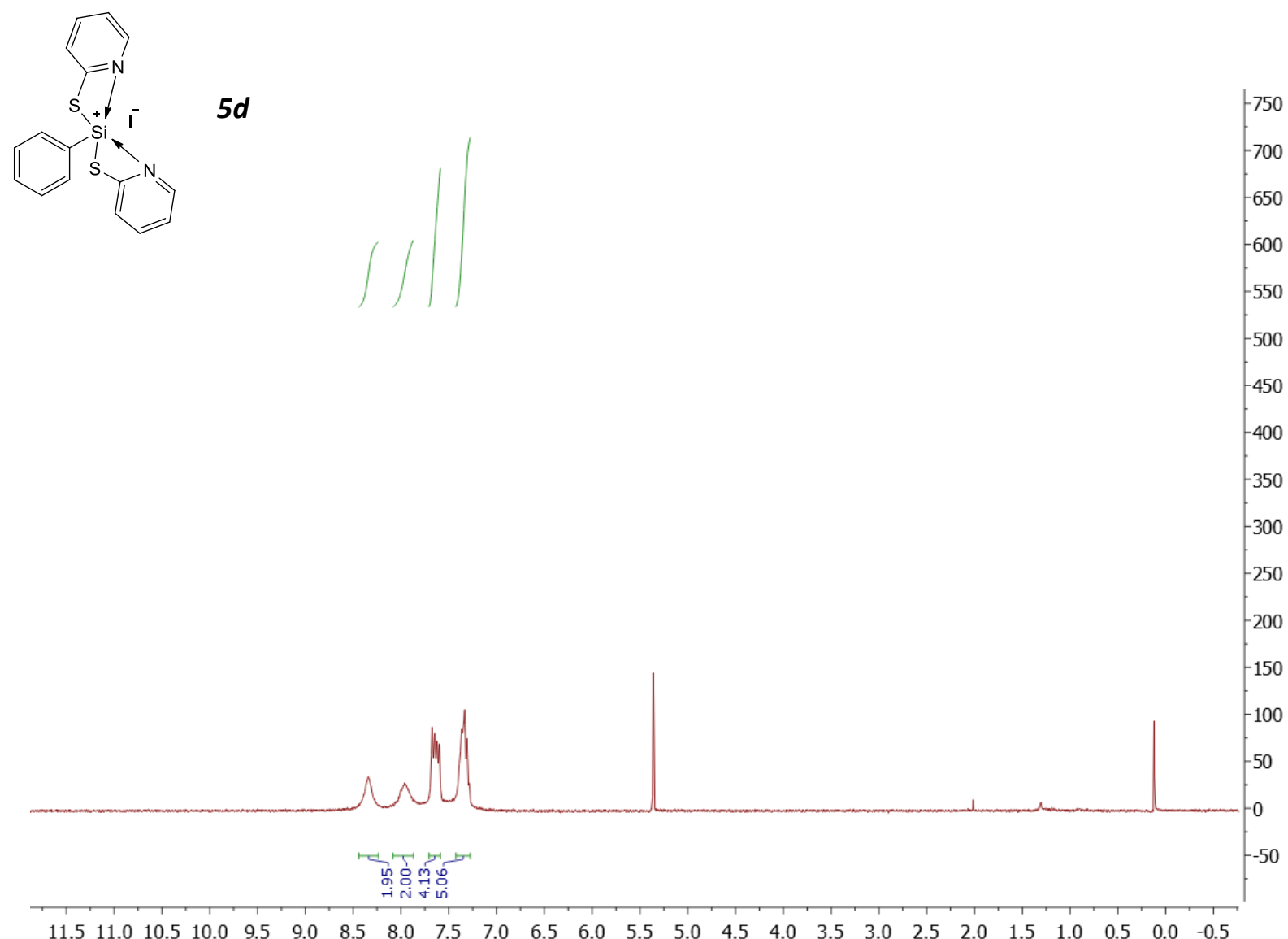

$\begin{array}{llllllllllllllllllllllll}11.5 & 11.0 & 10.5 & 10.0 & 9.5 & 9.0 & 8.5 & 8.0 & 7.5 & 7.0 & 6.5 & \underset{\mathrm{f} 1}{(\mathrm{pppm})} \mathbf{6 . 0} & 5.5 & 4.5 & 4.0 & 3.5 & 3.0 & 2.5 & 2.0 & 1.5 & 1.0 & 0.5 & 0.0 & -0.5\end{array}$ 

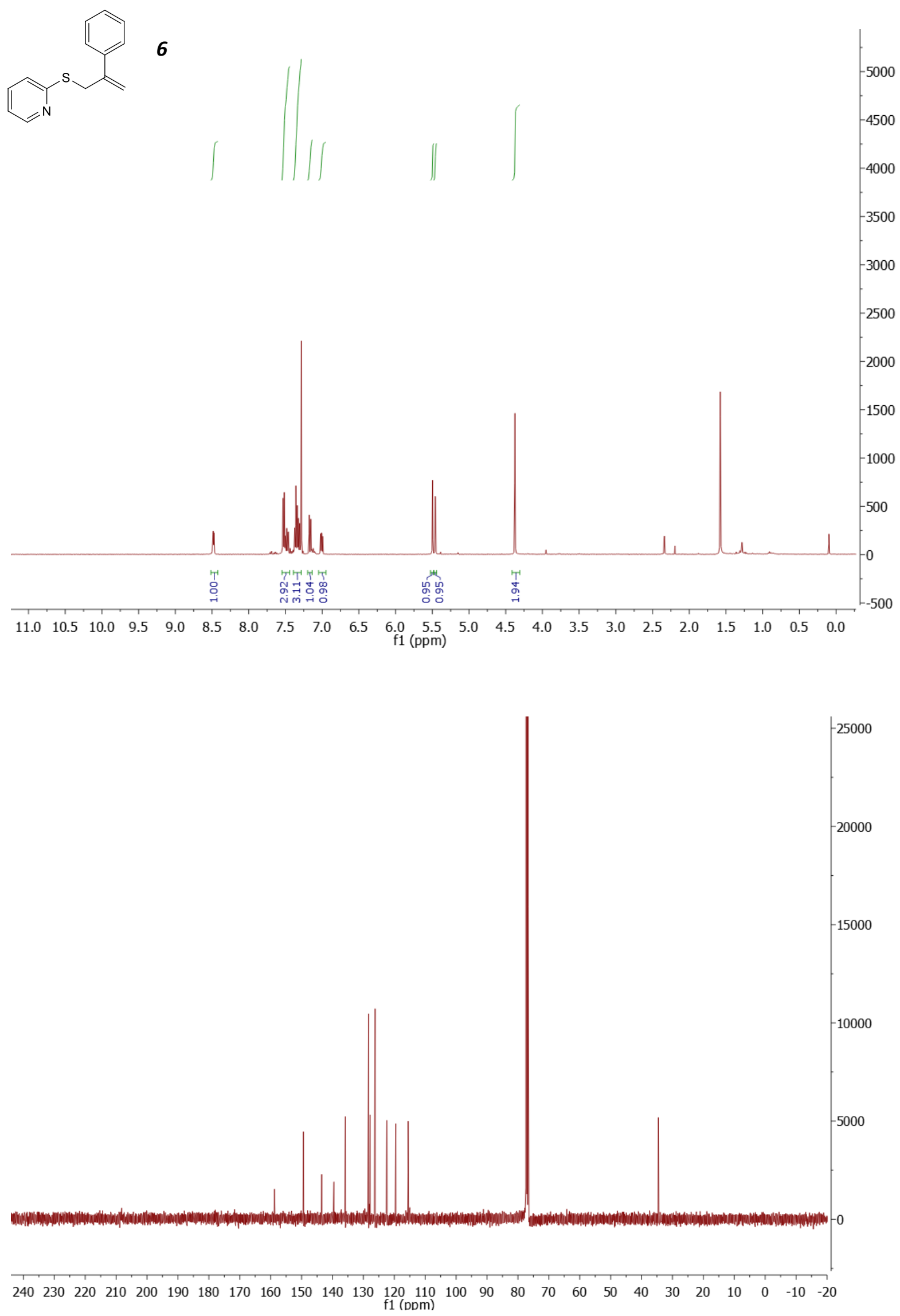

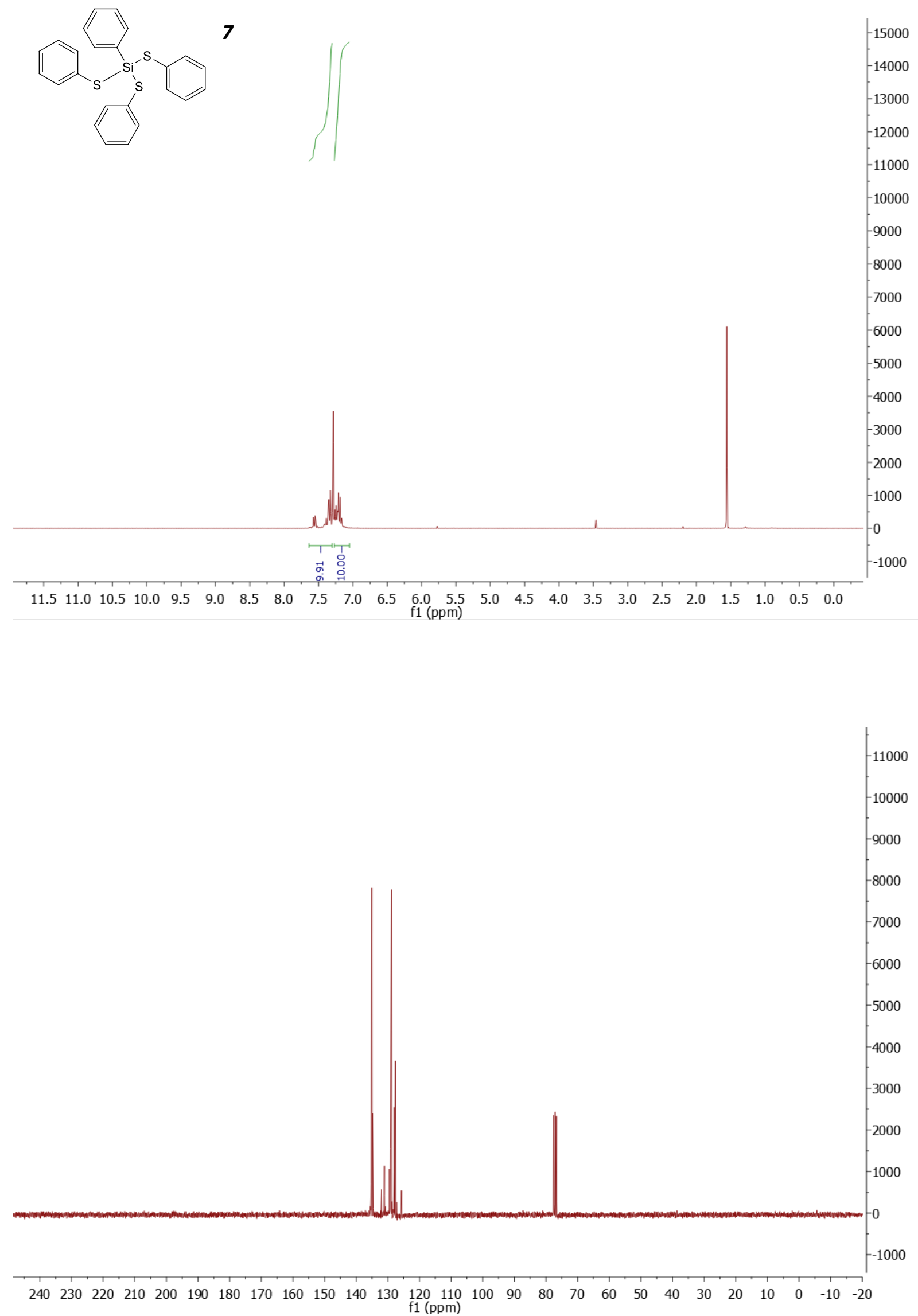